\title{
Magmatic sulfides in high-potassium calc-alkaline to shoshonitic and alkaline rocks
}

\author{
Ariadni A. Georgatou and Massimo Chiaradia \\ Department of Earth Sciences, University of Geneva, Rue des Maraichers 13, 1205 Geneva, Switzerland
}

Correspondence: Ariadni A. Georgatou (ariadni.georgatou@unige.ch)

Received: 5 June 2019 - Discussion started: 26 July 2019

Revised: 30 October 2019 - Accepted: 11 November 2019 - Published: 7 January 2020

\begin{abstract}
We investigate the occurrence and chemistry of magmatic sulfides and their chalcophile metal cargo behaviour during the evolution of compositionally different magmas from diverse geodynamic settings both in mineralised and barren systems. The investigated areas are the following: (a) the Miocene Konya magmatic province (hosting the Doğanbey $\mathrm{Cu}-\mathrm{Mo}$ porphyry and Inlice $\mathrm{Au}$ epithermal deposits, representing post-subduction) and (b) the Miocene Usak basin (Elmadag, Itecektepe, and Beydagi volcanoes, the latter associated with the Kişladağ Au porphyry in western Turkey, representing post-subduction). For comparison we also investigate (c) the barren intraplate PlioQuaternary Kula volcanic field west of Usak. Finally, we discuss and compare all the above areas with the already studied (d) Quaternary Ecuadorian volcanic arc (host to the Miocene Llurimagua $\mathrm{Cu}-\mathrm{Mo}$ and $\mathrm{Cascabel} \mathrm{Cu}-\mathrm{Au}$ porphyry deposits, representing subduction). The volcanism of the newly studied areas ranges from basalts to andesites-dacites and from high-K calc-alkaline to shoshonitic series. Multiphase magmatic sulfides occur in different amounts in rocks of all investigated areas, and, based on textural and compositional differences, they can be classified into different types according to their crystallisation at different stages of magma evolution (early versus late saturation). Our results suggest that independently of the magma composition, geodynamic setting, and association with an ore deposit, sulfide saturation occurred in all investigated magmatic systems. Those systems present similar initial metal contents of the magmas. However, not all studied areas present all sulfide types, and the sulfide composition depends on the nature of the host mineral. A decrease in the sulfide $\mathrm{Ni} / \mathrm{Cu}$ (a proxy for the monosulfide solid solution (mss) to intermediate solid solution (iss) ratio) is noted with magmatic evolution. At an early
\end{abstract}

stage, Ni-richer, $\mathrm{Cu}$-poorer sulfides are hosted by early crystallising minerals, e.g. olivine-pyroxene, whereas, at a later stage, $\mathrm{Cu}$-rich sulfides are hosted by magnetite. The most common sulfide type in the early saturation stage is composed of a $\mathrm{Cu}$-poor, Ni-rich (pyrrhotite mss) phase and one to two $\mathrm{Cu}$-rich (cubanite, chalcopyrite iss) phases, making up $\sim 84$ and $\sim 16$ area $\%$ of the sulfide, respectively. Sulfides resulting from the late stage, consisting of $\mathrm{Cu}$-rich phases (chalcopyrite, bornite, digenite iss), are hosted exclusively by magnetite and are found only in evolved rocks (andesites and dacites) of magmatic provinces associated with porphyry $\mathrm{Cu}$ (Konya and Ecuador) and porphyry Au (Beydagi) deposits.

\section{Introduction}

Historically, petrographic and mineral chemistry studies of magmatic sulfides have been carried out on magmatic sulfides associated with orthomagmatic Ni-Cu-PGEmineralised systems (PGE - platinum-group elements; e.g. Barnes et al., 2017; Mungall and Brenan, 2014). Recent studies, however, highlight the growing research interest in magmatic sulfides in porphyry ore-associated magma (e.g. Halter et al., 2005; Brennecka, 2006; Zhang and Audétat, 2017) and in barren volcanic arc provinces (e.g. Nadeau et al., 2010; Park et al., 2015; Fulignati et al., 2018; Zelenski et al., 2017; Keith et al., 2017; Savelyev et al., 2018) in order to track processes affecting the fertility of these systems. In fact, it is still unclear how sulfide saturation affects the process of magmatic-hydrothermal ore formation. On the one hand, early sulfide saturation will strip off chalcophile and siderophile elements from the melt, rendering the residual melt less fertile. On the other hand, magmatic sulfide- 
and metal-rich cumulates may represent a temporary storage, which subsequently releases chalcophile metals to the magmatic hydrothermal system (e.g. Nadeau et al., 2010; Wilkinson, 2013; Fontboté et al., 2017).

Georgatou et al. (2018) described the occurrence, texture, and composition of magmatic sulfides in relation to the whole rock chemistry of Quaternary Ecuadorian volcanic rocks. Sulfides were found in all rocks ranging in composition from basalts to dacites, occurring as polymineralic inclusions composed of $\mathrm{Fe}$-rich, $\mathrm{Cu}$-poor, and $\mathrm{Cu}$-rich phases. The inclusions, of variable size (mostly $1-30 \mu \mathrm{m})$ and shape (globular, ellipsoidal, angular, and irregular), were hosted mostly by Fe oxides (magnetite $-45 \%$ ) and, to a lesser extent, by silicates (amphibole $-27 \%$, plagioclase $-16 \%$, and pyroxene $-12 \%)$. The Quaternary Ecuadorian volcanism represents a typical example of high-Sr/Y calc-alkaline magmas (with $\mathrm{SiO}_{2}=50 \mathrm{wt} \%-67 \mathrm{wt} \%$ ) occurring in a subduction geodynamic setting potentially related (Loucks, 2014; Chiaradia and Caricchi, 2017) to porphyry-type deposits (e.g. the Llurimagua $\mathrm{Cu}-\mathrm{Mo}$ and Cascabel $\mathrm{Cu}-\mathrm{Au}$ Tertiary porphyry deposits and the El Corazon high-sulfidation $\mathrm{Au}$ Miocene epithermal deposit).

Although the majority of porphyry $\mathrm{Cu}( \pm \mathrm{Au})$ deposits are formed in association with subduction-related magmas (e.g. Sillitoe, 1972; Cooke et al., 2005) there is a growing evidence that porphyry deposits are also related to post-subduction magmatism (Richards, 2009). The porphyry deposits found in both these settings present similarities in terms of mineralisation and alteration styles but also differences concerning the petrogenesis and geochemistry of associated magmas (Shafiei et al., 2009; Richards, 2009; Hou et al., 2011). By comparing the occurrence and composition of magmatic sulfides found in volcanic rocks from different geodynamic settings (which may host porphyry and epithermal deposits; Fig. 1), it is possible to investigate the role of magmatic sulfide saturation with respect to the fertility of the ore-forming systems (e.g. Park et al., 2019; Blundy et al., 2015; Wilkinson, 2013; Audétat and Simon, 2012; Nadeau et al., 2010; Jenner et al., 2010).

In order to investigate the magmatic sulfide occurrence in volcanic rocks characterised by a post-subduction geodynamic setting, we focus our study on three volcanic areas located in western Anatolia (Turkey), namely the Konya volcanic belt, the Usak basin (Elmadag, Itecektepe, and Beydagi volcanoes), and the Kula volcanic field (Fig. 2). The investigated areas represent a suitable integration of and comparison to the Ecuadorian study (Georgatou et al., 2018) for the following reasons: (i) the wide range of $\mathrm{SiO}_{2}$ content (43 wt \%-70 wt \%) and alkalinity (from high-K calc-alkaline to shoshonitic and alkaline affinities) characterising the volcanic rocks, (ii) the occurrence of both $\mathrm{Cu}$ - and $\mathrm{Au}$-rich porphyry and epithermal-type deposits (Doğanbey Cu porphyry, Inlice Au epithermal in Konya, and Kişladağ Au porphyry in Beydagi) temporally associated with magmatic rocks of these areas, and (iii) the inclusion of the intraplate mafic al- kaline volcanic field of Kula, which is not associated with any type of mineralisation.

Compared to the majority of previous studies, which focused only on uncovered sulfides hosted in transparent to semitransparent minerals, by investigating uncovered sulfides we are able to include opaque host minerals (e.g. magnetite, which was a major sulfide host phase for the case of Ecuador; Georgatou et al., 2018) while maintaining the textural relations not only between the sulfide, its host mineral, and the surrounding minerals but also within the sulfide inclusion itself.

\section{Geology, magmatism, and mineralisation in western Anatolia}

The geodynamic regime in western Anatolia switched from a subduction setting during the Upper Cretaceous to a collisional setting in the late Paleocene, resulting in postcollisional extension in the Eocene (Delibaş et al., 2016, 2017; Rabayrol et al., 2019; see Fig. 2a for the general geodynamic setting). Several volcano(-plutonic) complexes of Mio-Pliocene age occur in NE-SW-trending extensional basins and are post-orogenic extensional in nature. They have been divided into three regions (Fig. 2b, c): (i) the Konya region, for which both subduction (Doglioni et al., 2002, 2009; Innocenti et al., 2005) and post-subduction (PePiper and Piper, 2001; Dilek and Altunkaynak, 2007) geodynamic regimes have been suggested, is taken here to represent a post-subduction geodynamic regime as supported by recent evidence presented by Rabayrol et al. (2019); (ii) the Usak-Güre basin, including three volcanic centres (Elmadag, Itecektepe and Beydagi), corresponds to a post-subduction, locally extensional setting (Prelević et al., 2012; Ersoy et al., 2010); and (iii) the Kula volcanic field results from asthenospheric upwelling associated with extension in a postsubduction setting (Tokçaer et al., 2005; Alici et al., 2002).

\subsection{Konya}

The Konya volcanic belt is located S-SW of the city of Konya (Fig. 2b). It is composed of volcanic domes and ignimbrites of mid-Miocene to Pliocene age (Keller et al., 1977; Temel, 2001). The basement includes Permian metamorphic rocks, Triassic limestone and shales, Jurassic ophiolites, radiolarites, and limestones, and Cretaceous sandstones and quartzites (Temel et al., 1998). The erupted products are andesites to dacites with high-K calc-alkaline affinity. According to K/Ar ages obtained by Keller et al. (1997), a southwestern migration of magmatism is observed with time, starting with the oldest unit, the Sille volcanics (11.45-11.9 Ma), located in the northeastern part of the Konya volcanic and ending with the Fasillar and Gevrekli domes in the SW of the volcanic belt, which show Pliocene ages (3.75 and $3.35 \mathrm{Ma}$, respectively). 


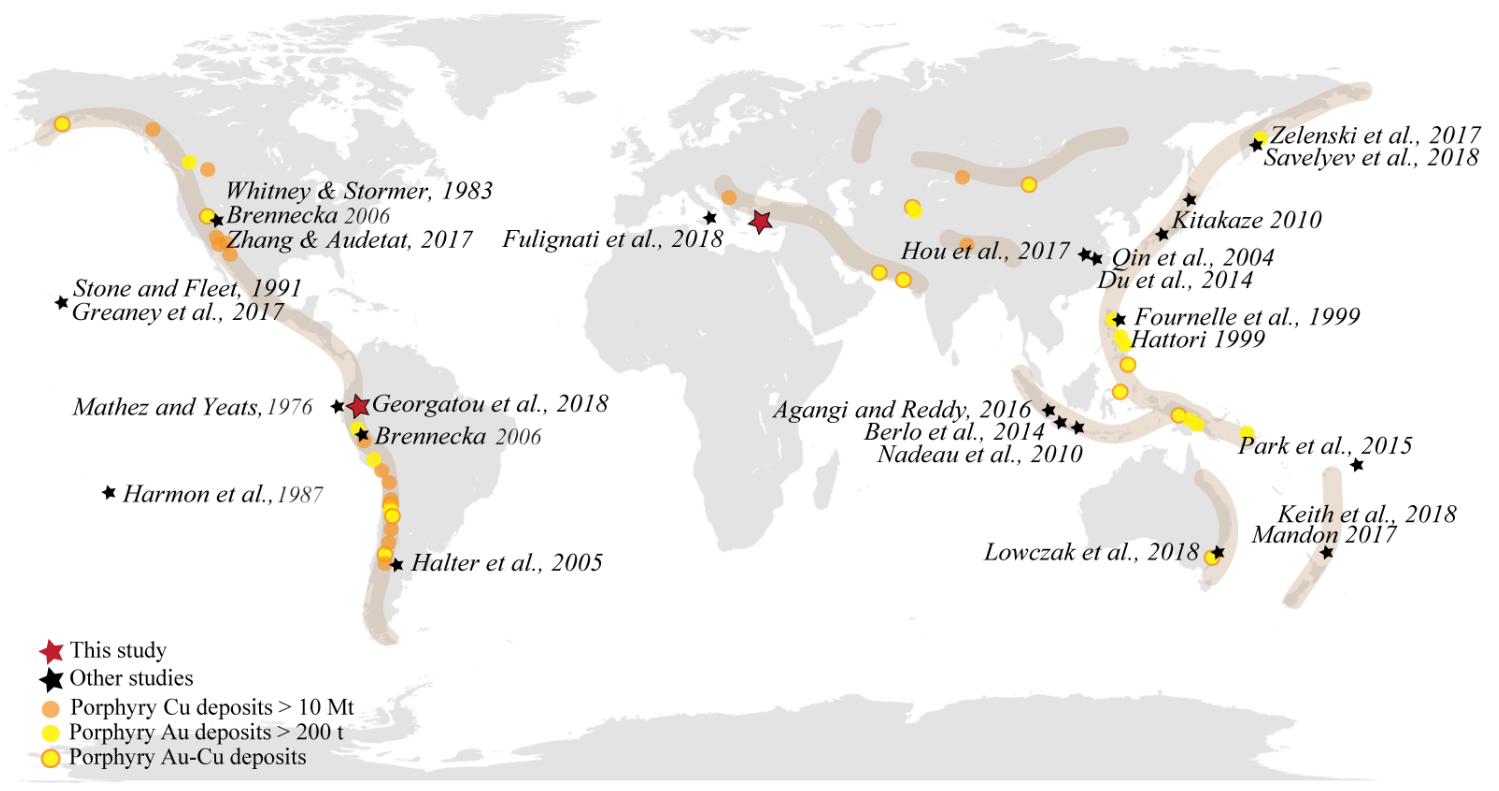

Figure 1. World distribution of arc-related metallogenic belts, showing the biggest $\mathrm{Cu}$ and/or Au porphyry deposits; modified from Richards (2013) and Cooke et al. (2005). References of previous studies on magmatic sulfides are depicted with black stars, whereas the areas considered in this study are shown with a bigger red star.

The Konya volcanic belt hosts the Miocene Au epithermal high-sulfidation deposit of Inlice $\left(1.68 \mathrm{t}\right.$ at $2.36 \mathrm{~g} \mathrm{t} \mathrm{Au}^{-1}$; https://mining-atlas.com, last access: 5 October 2010) and the Miocene-Pliocene Doğanbey $\mathrm{Cu}$ porphyry deposit (drilling of $273.90 \mathrm{~m}$ at $0.13 \mathrm{~g} \mathrm{t} \mathrm{Au}^{-1}$; Stratex International Plc, 2018), both shown in Fig. 2b. Two other prospects (Karacaören and the Oğlakçı) have been discovered by Stratex International in the Konya volcanic belt. For details on the mentioned economic deposits, please see Zürcher et al. (2015) for Inlice and Redwood (2006) and Hall et al. (2007) for Doğanbey.

\subsection{Usak-Güre basin}

The Usak-Güre basin, situated $300 \mathrm{~km}$ west of the Konya volcanic belt, is composed of (i) the Menders Massif, including a metamorphic core composed of metagranites and gneiss (Proterozoic) overlain by Paleozoic schists and Mesozoic marbles, and of (ii) the Upper Cretaceous Ophiolitic mélange of the Izmir-Ankara zone, including unmetamorphosed ultramafic rocks, radiolarites, and altered silicic rocks (Ercan et al., 1978; Çemen et al., 2006). Syn-extensional sedimentation and volcanism associated with the metamorphic complex of the Menders Massif are recorded in detail within the basin. From the early to mid-Miocene, the basin contains three sequences: the Hacibekir Group, the Inay Group, and the Asartepe formation, represented by volcanic and metamorphic rocks (Çemen et al., 2006; Karaoğlu et al., 2010). The Cenozoic volcanism in the Usak-Güre basin occurs in three NE-SW-trending belts wherein the volcanic edifices are aligned. According to the ages obtained by Karaoğlu et al. (2010) and Seyitoglu (1997) it appears that the volcanism migrated from north to south with time: (i) Elmadag (17.29 Ma), (ii) Itecektepe (15.04 Ma), and (iii) Beydagi (12.15 Ma) (see Fig. 2c). Volcanic products include shoshonites, latites, and rhyolitic lavas, followed by dacitic and andesitic pyroclastic deposits. All three volcanoes are composed of dacitic ignimbrites formed by the collapse of their caldera and overlying lava flows.

Among all the volcanic complexes situated in the UsakGüre basin only the Beydagi complex is mineralised, hosting the Kişladağ Au porphyry $\left(255 \mathrm{t}\right.$ at $0.61 \mathrm{~g} \mathrm{t} \mathrm{Au}^{-1}$ and $119 \mathrm{t}$ at $0.4 \mathrm{~g} \mathrm{t} \mathrm{Au}^{-1}$ of total indicated and inferred resources, respectively (Baker et al., 2016), with cut-off grade $0.3 \mathrm{~g} \mathrm{t}^{-1}$ and up to $327 \mathrm{ppm}$ of Mo (Sillitoe, 2002); https://www. eldoradogold.com, last access: 30 September 2018).

\subsection{Kula volcanic field}

The Kula volcanic field is situated west of the Usak province (Fig. 2c), and its volcanic products are late Pliocene to late Quaternary in age (Ercan and Oztunali, 1982; Ercan et al., 1983; Richardson-Bunbury, 1996; Innocenti et al., 2005; Aldanmaz, 2002; Westaway et al., 2004). The rocks include lava flows and tephra deposits of varying mafic alkaline composition (basanite, phonolitic tephrite and trachybasalt). Kula represents an intraplate ocean-island-basalt-like (OIB-like) alkali-basaltic volcanic centre with an asthenospheric mantle signature and no subduction-related inputs (e.g. Agostini et al., 2007; Alici et al., 2002; Tokçaer et al., 2005). 


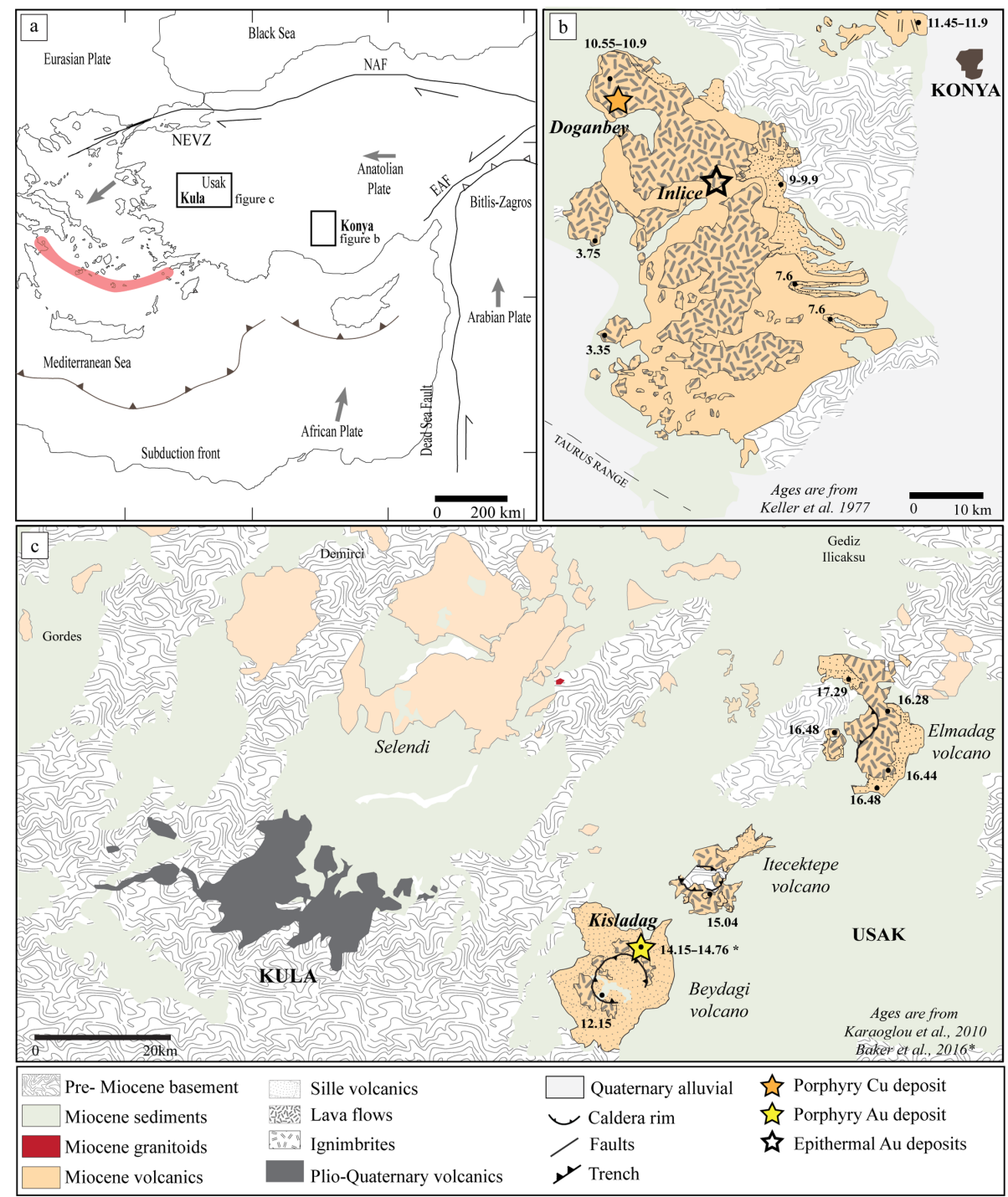

Figure 2. Tectonic (a) and geological maps (b-c) of the studied areas and associated Au epithermal and Cu-Au porphyry deposits in western Anatolia. The investigated Miocene volcano-plutonic complexes are Konya (b) and the volcanoes of the Usak basin (Elmadag, Itecektepe, and Beydagi - c) as well as the Quaternary Kula volcano (c). The geological maps have been modified after (b) Keller et al. (1977) and (c) Karaoğlu et al. (2010).

\section{Analytical methods}

After a preliminary screening for magmatic sulfides in 108 thin sections from all investigated volcanic centres, a total of 93 thin polished sections were studied in detail under a petrographic microscope both in transmitted and reflected light (Table S1 in Supplement S1). Thin sections that had both hydrothermal and magmatic sulfides were excluded from this study due to the difficulty in some cases to distinguish between these two types of sulfides (see distinguishing criteria in Supplement S2). For this reason, unless stated otherwise, the sulfides referred to herein are always meant to be magmatic sulfides. Microphotographs and identification criteria of mineral phases were obtained using a scan- ning electron microscope (SEM; JEOL JSM7001F digital) with $15 \mathrm{kV}$ accelerating potential and a $1 \mathrm{nA}$ absorbed current at the University of Geneva, Switzerland. Whole rock samples were analysed for major and minor elements by Xray fluorescence (XRF) analysis using a PANalytical Axiom AX spectrometer and for trace elements by a laser ablationinductively coupled plasma mass spectrometer (LA-ICP-MS; Agilent 7700) at the University of Lausanne, Switzerland (Tables 1-3 at https://doi.org/10.6084/m9.Figshare.8230787; Georgatou and Chiaradia, 2019). In situ chemical analysis of sulfides (Table 1) was carried out using a JEOL 8200 probe microanalyser (EPMA) at the University of Geneva, Switzerland (for the complete dataset, see Table 4 from Georgatou and Chiaradia, 2019). Image analysis software (Im- 
ageJ(C) 1.38 software) was used to obtain modal abundances of the phases composing each sulfide in order to reconstruct the bulk area percent sulfide composition (for the complete dataset, see Table 5 from Georgatou and Chiaradia, 2019). For details on analytical methods and their limitations, see Supplement S2.

\section{Results}

\subsection{Whole rock geochemistry}

The volcanic rocks of the studied areas display a wide range of $\mathrm{SiO}_{2}$ and alkali element concentrations ranging from basalts to andesites-dacites with high-K calc-alkaline to shoshonitic affinity (Fig. 3a, b). The Konya volcanic belt is characterised by volcanic products ranging from andesitic to dacitic in composition with a high-K calc-alkaline affinity. In the Usak basin, the Elmadag volcanic complex is composed mostly of shoshonitic trachyandesites, the Itecektepe volcanic unit is characterised by high-K calc-alkaline rocks, mostly andesitic in composition, and the Beydagi volcanic edifice contains rocks ranging from andesites to trachyandesites with high-K calc-alkaline to shoshonitic affinity. Finally, the Kula Quaternary volcano presents the most alkaline and mafic compositions, ranging from tephrites-basanites to phonotephrites. All rocks present a negative correlation of $\mathrm{TiO}_{2}$ and $\mathrm{Fe}_{2} \mathrm{O}_{3}$ with $\mathrm{SiO}_{2}$, with Kula being more enriched in $\mathrm{TiO}_{2}$ and $\mathrm{Fe}_{2} \mathrm{O}_{3}$ than the rest.

In terms of trace element concentrations all rocks show a decrease in $\mathrm{Cu}$ and $\mathrm{Ni}$ with an increase in $\mathrm{SiO}_{2}$ (Fig. 3e-f), indicating a compatible behaviour of these elements during magmatic evolution. In addition, all rocks show an enrichment of light relative to heavy rare-earth elements with decreasing $\mathrm{Nb}$, Ta, and $\mathrm{Ni}$ passing from intraplate volcanism (Kula) to post-subduction (Elmadag, Itecektepe, Beydagi, Konya).

\subsection{Sample petrography}

All studied samples are volcanic rocks with porphyritic textures. Phenocrysts are usually plagioclase, amphibole, pyroxene (mostly clinopyroxene), and, depending on the volcanic centre, olivine, biotite, and to a lesser extent Fe-Ti oxides (mostly Ti-magnetite). The matrix is aphanitic, mostly composed of microlitic plagioclase $(<1 \mathrm{~mm})$ and sometimes amphibole and pyroxene microcrystals. Apatite and anhydrite can also be found as inclusions in pyroxene and Fe-Ti oxide phenocrysts.

\subsection{Sulfide petrography and chemistry}

Rocks of all study areas contain magmatic sulfides. However, depending on the volcanic centre, sulfides are present in variable amounts, sizes, shapes, and compositions. A comparison of the sulfide occurrences among the different volcanic cen- tres (also corresponding to different geodynamic settings) is given in Fig. 4. In all studied samples sulfides occur inside phenocrysts and not in the groundmass (Fig. 5), with the exception of the Kula volcano that also presents sulfides as aggregates with oxides and micro-sized silicates in the groundmass (Figs. 4e, xi, 5e) and a few cases in Beydagi (Fig. 4xii). The main host phenocryst for sulfides is magnetite for Konya and Beydagi (42\% and $31 \%$, respectively), amphibole for Itecektepe and Kula (85\% and 39\%), and pyroxene for Elmadag $(87 \%)$. Sulfides are also hosted in plagioclase. The common occurrence of voids and/or vesicles in contact with the sulfide phases is noteworthy (e.g. Figs. 4v, vii, x, 5g, 6i, f).

Based on petrographic observations and SEM mineral analysis we distinguished six main types of magmatic sulfides: (1) Type 1 sulfides containing two to three distinct phases, namely a $\mathrm{Cu}$-poor and Ni-rich phase (pyrrhotite), an Ni-rich phase (pentlandite), and rarely a $\mathrm{Cu}$-rich phase (cubanite) (Fig. 4a); (2) Type 2 sulfides containing two to four distinct phases, namely a $\mathrm{Cu}$-poor (pyrrhotite), one to two $\mathrm{Cu}$-rich (chalcopyrite \pm cubanite), and sometimes an $\mathrm{Ni}$ rich (pentlandite) phase (Fig. 4b); (3) Type 3 sulfides containing a $\mathrm{Cu}$-rich phase (chalcopyrite or chalcocite) and an Fe-rich phase (pyrite/Fig. 4c); (4) Type 4 sulfides containing only $\mathrm{Cu}$-rich phase(s) (chalcopyrite, \pm cubanite, \pm bornite), occasionally in contact with anhydrite (Fig. 4d); and (5) Type 5 sulfides containing aggregates of a $\mathrm{Cu}$-poor and Ni-rich (pyrrhotite) sulfide phase and one or more Al-rich oxide phases (magnetite, magnetite-ilmenite, and secondary goethite) (Fig. 4e). Finally, Type 6 sulfides, the so-called "daughter sulfides" (e.g. Savelyev et al., 2018; Fig. 5h), were only observed in three cases in this study within olivine phenocrysts of rocks from Kula. From SEM analysis this latter sulfide type it is composed only of pyrrhotite \pm pentlandite; however, due to their small size $(<0.5 \mu \mathrm{m})$ they could not be analysed with the EPMA.

Type 1 sulfides are only hosted by olivine; they are generally small $(<30 \mu \mathrm{m})$, round, and show pentlandite exsolution flames in pyrrhotite (Fig. 4i). Type 2 sulfides, the most common, are hosted by different phenocrysts (pyroxene, amphibole, magnetite, and plagioclase), presenting a range of sizes (up to $70 \mu \mathrm{m}$ ) and having mostly ellipsoidal to rounded shape (Fig. 4ii-vii). The pentlandite phase in this sulfide type can occur either as an exsolution in the pyrrhotite and/or as an individual phase inside the Ni-rich pyrrhotite (Fig. 4vi), whereas cubanite is mostly present when the sulfide is hosted in amphibole, forming complex exsolution textures with chalcopyrite and presenting irregular roundedresorbed shapes (Fig. 5d). Type 3 and 4 sulfides are only hosted by magnetite phenocrysts occurring in smaller sizes $(<30$ and $<20 \mu \mathrm{m})$ and presenting ellipsoidal and angular shapes, respectively (Fig. 4viii, ix, x). Type 4 sulfides have been observed in some cases in contact with anhydrite and with zircon inclusions (usually $<20 \mu \mathrm{m}$ ) all hosted by the same magnetite crystal (Fig. 6). Finally, Type 5 consists of 
Table 1. EPMA summary for individual sulfide analysis ( $N$ is the number of measurements) corresponding to each sulfide type for every study area. The empty cells (-) correspond to a lack of measurement either because it was below the determination limit or not measured. For the complete dataset, analytical conditions, and detection limits, see Table 4 from Georgatou and Chiaradia (2019).

\begin{tabular}{|c|c|c|c|c|c|c|c|c|c|c|c|c|c|c|}
\hline \multirow[t]{2}{*}{ Area } & \multirow[t]{2}{*}{ Type $(N)$} & & \multicolumn{2}{|c|}{ Whole rock chemistry } & \multicolumn{10}{|c|}{ EPMA sulfide chemistry (wt \%) } \\
\hline & & & $\mathrm{Cu}$ ppm & $\mathrm{SiO}_{2}$ wt $\%$ & $S$ & $\mathrm{Cu}$ & $\mathrm{Fe}$ & $\mathrm{Ni}$ & As & $\mathrm{Se}$ & $\mathrm{Zn}$ & $\mathrm{Ag}$ & $\mathrm{Au}$ & Tot \\
\hline \multirow{15}{*}{ 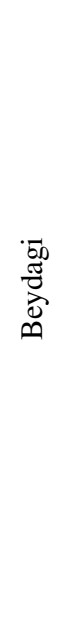 } & \multirow[t]{5}{*}{$2(17)$} & med & 7 & 62 & 38 & 0.3 & 55 & 0.15 & 0.03 & 0.02 & 0.5 & 0.02 & 0.22 & 98 \\
\hline & & $\min$ & 4.2 & 46 & 35 & 0.01 & 29 & 0.03 & 0.03 & 0.02 & 0.5 & 0.01 & 0.15 & - \\
\hline & & $\max$ & 29 & 72 & 53 & 34 & 58 & 0.77 & 0.03 & 0.02 & 0.5 & 0.02 & 0.27 & - \\
\hline & & av & 12 & 62 & 40 & 6.6 & 49 & 0.31 & 0.03 & 0.02 & 0.5 & 0.02 & 0.22 & 99 \\
\hline & & SD & 6.7 & 3.9 & 5.7 & 11 & 10 & 0.28 & - & - & - & - & 0.05 & - \\
\hline & \multirow[t]{5}{*}{$3(16)$} & med & 18 & 59 & 35 & 32 & 31 & 0.12 & 0.07 & 0.03 & 0.98 & 0.01 & 0.24 & 99 \\
\hline & & $\min$ & 6.7 & 59 & 33 & 0.17 & 31 & 0.01 & 0.07 & 0.03 & 0.73 & 0.01 & 0.24 & - \\
\hline & & $\max$ & 18 & 63 & 53 & 33 & 58 & 1.21 & 0.07 & 0.03 & 3 & 0.02 & 0.24 & - \\
\hline & & av & 17 & 59 & 38 & 24 & 35 & 0.32 & 0.07 & 0.03 & 1.4 & 0.01 & 0.24 & 99 \\
\hline & & SD & 2.8 & 1 & 6.1 & 13 & 7.6 & 0.43 & - & - & 0.9 & - & - & - \\
\hline & \multirow[t]{5}{*}{$5(6)$} & med & 6.7 & 63 & 38 & 0.78 & 56 & 0.04 & - & - & 0.71 & 0.02 & 0.14 & 97 \\
\hline & & $\min$ & 6.7 & 59 & 33 & 0.08 & 29 & 0.01 & - & - & 0.59 & 0.02 & 0.14 & - \\
\hline & & $\max$ & 18 & 63 & 51 & 32 & 58 & 0.21 & - & - & 2.4 & 0.02 & 0.14 & - \\
\hline & & av & 10 & 61 & 38 & 11 & 47 & 0.07 & - & - & 1.2 & 0.02 & 0.14 & 97 \\
\hline & & SD & 5.6 & 2.1 & 5.3 & 15 & 13 & 0.07 & - & - & 1.03 & - & - & - \\
\hline \multirow{5}{*}{ 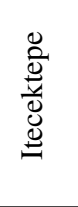 } & \multirow[t]{5}{*}{$2(26)$} & med & 7 & 62 & 38 & 0.03 & 57 & 0.1 & - & 0.04 & 0.81 & 0.02 & 0.18 & 97 \\
\hline & & $\min$ & 5.1 & 61 & 35 & 0.01 & 52 & 0.02 & - & 0.04 & 0.57 & 0.01 & 0.18 & - \\
\hline & & $\max$ & 13 & 64 & 39 & 6.1 & 58 & 0.25 & - & 0.04 & 1.5 & 0.03 & 0.18 & - \\
\hline & & av & 7.2 & 62 & 38 & 0.27 & 57 & 0.1 & - & 0.04 & 0.88 & 0.02 & 0.18 & 97 \\
\hline & & SD & 1.6 & 0.85 & 0.85 & 1.2 & 1.3 & 0.05 & - & - & 0.34 & 0.01 & - & - \\
\hline \multirow{5}{*}{ 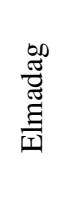 } & \multirow[t]{5}{*}{$2(8)$} & med & 26 & 61 & 37 & 0.14 & 56 & 0.26 & 0.04 & - & 0.75 & 0.02 & - & 96 \\
\hline & & $\min$ & 4.3 & 56 & 35 & 0.01 & 32 & 0.04 & 0.04 & - & 0.72 & 0.02 & - & - \\
\hline & & $\max$ & 63 & 69 & 39 & 29 & 58 & 1.5 & 0.04 & - & 0.79 & 0.02 & - & - \\
\hline & & av & 26 & 61 & 37 & 4.2 & 53 & 0.4 & 0.04 & - & 0.75 & 0.02 & - & 96 \\
\hline & & SD & 12 & 2.9 & 1.29 & 11 & 8.73 & 0.47 & - & - & 0.05 & - & - & - \\
\hline \multirow{15}{*}{$\frac{\pi}{\Xi}$} & \multirow[t]{5}{*}{$1(10)$} & med & 29 & 47 & 38 & 0.05 & 56 & 4.2 & 0.04 & 0.02 & - & & 0.04 & 98 \\
\hline & & $\min$ & 29 & 47 & 36 & 0.03 & 45 & 3 & 0.03 & 0.02 & - & - & 0.04 & - \\
\hline & & $\max$ & 30 & 48 & 39 & 0.34 & 57 & 14 & 0.06 & 0.03 & - & - & 0.04 & - \\
\hline & & av & 29 & 48 & 38 & 0.15 & 54 & 6 & 0.04 & 0.02 & - & - & 0.04 & 98 \\
\hline & & SD & 0.25 & 0.35 & 0.76 & 0.14 & 4.4 & 4.3 & 0.01 & - & - & - & - & - \\
\hline & \multirow[t]{5}{*}{$2(190)$} & med & 29 & 47 & 38 & 0.1 & 58 & 0.77 & 0.04 & 0.04 & 0.03 & 0.02 & 0.05 & 98 \\
\hline & & $\min$ & 23 & 37 & 38 & 0.01 & 5.8 & 0.01 & 0.02 & 0.02 & 0.02 & 0.01 & 0.03 & - \\
\hline & & $\max$ & 61 & 66 & 40 & 32 & 62 & 41 & 0.1 & 0.08 & 0.16 & 0.04 & 0.22 & - \\
\hline & & av & 30 & 47 & 36 & 2.4 & 54 & 2.9 & 0.05 & 0.04 & 0.05 & 0.02 & 0.06 & 98 \\
\hline & & SD & 4.2 & 1.7 & 5.9 & 6.3 & 10 & 7.3 & 0.02 & 0.01 & 0.04 & 0.01 & 0.04 & - \\
\hline & \multirow[t]{5}{*}{$5(35)$} & med & 29 & 47 & 37 & 0.45 & 59 & 0.78 & 0.05 & 0.03 & 0.03 & 0.02 & 0.04 & 98 \\
\hline & & $\min$ & 28 & 47 & 33 & 0.01 & 35 & 0.04 & 0.02 & 0.02 & 0.02 & 0.01 & 0.03 & - \\
\hline & & $\max$ & 35 & 48 & 40 & 26 & 61 & 22 & 0.08 & 0.06 & 0.16 & 0.05 & 0.11 & - \\
\hline & & av & 30 & 47 & 37 & 4.7 & 55 & 1.8 & 0.05 & 0.04 & 0.05 & 0.02 & 0.05 & 98 \\
\hline & & SD & 2.6 & 0.31 & 1.8 & 8.5 & 8.3 & 4.1 & 0.01 & 0.01 & 0.04 & 0.01 & 0.02 & - \\
\hline
\end{tabular}


Table 1. Continued.

\begin{tabular}{|c|c|c|c|c|c|c|c|c|c|c|c|c|c|c|}
\hline \multirow[t]{2}{*}{ Area } & \multirow[t]{2}{*}{ Type $(N)$} & & \multicolumn{2}{|c|}{ Whole rock chemistry } & \multicolumn{10}{|c|}{ EPMA sulfide chemistry (wt \%) } \\
\hline & & & $\mathrm{Cu}$ ppm & $\mathrm{SiO}_{2}$ wt $\%$ & $S$ & $\mathrm{Cu}$ & $\mathrm{Fe}$ & $\mathrm{Ni}$ & As & $\mathrm{Se}$ & $\mathrm{Zn}$ & $\mathrm{Ag}$ & $\mathrm{Au}$ & Tot \\
\hline \multirow{10}{*}{$\begin{array}{l}\widetilde{\widehat{\Xi}} \\
\stackrel{\Xi}{\mathscr{\Delta}}\end{array}$} & \multirow[t]{5}{*}{$2(187)$} & med & 12 & 61 & 38 & 0.09 & 58 & 0.11 & 0.04 & 0.02 & 0.04 & 0.05 & - & 97 \\
\hline & & $\min$ & 4.6 & 46 & 26 & 0.01 & 15 & 0.01 & 0.02 & 0.01 & 0.01 & 0.01 & - & - \\
\hline & & $\max$ & 50 & 70 & 48 & 69 & 60 & 9.4 & 0.08 & 0.05 & 0.23 & 0.11 & - & - \\
\hline & & av & 13 & 62 & 37 & 4.2 & 55 & 0.23 & 0.04 & 0.02 & 0.04 & 0.05 & - & 96 \\
\hline & & SD & 4.8 & 2.9 & 3.2 & 11 & 8.7 & 0.79 & 0.02 & 0.01 & 0.04 & 0.03 & - & - \\
\hline & \multirow[t]{5}{*}{4 (19) } & med & 13 & 62 & 26 & 56 & 16 & 0.01 & 0.05 & 0.02 & 0.06 & 0.06 & - & 99 \\
\hline & & $\min$ & 12 & 61 & 22 & 38 & 5.6 & 0.01 & 0.02 & 0.02 & 0.06 & 0.04 & - & - \\
\hline & & $\max$ & 21 & 62 & 33 & 72 & 29 & 0.11 & 0.06 & 0.02 & 0.06 & 0.07 & - & - \\
\hline & & av & 14 & 62 & 27 & 54 & 18 & 0.02 & 0.04 & 0.02 & 0.06 & 0.06 & - & 99 \\
\hline & & SD & 3.5 & 0.33 & 3.1 & 11 & 7.1 & 0.02 & 0.02 & - & - & 0.01 & - & - \\
\hline \multirow{10}{*}{ 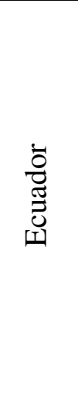 } & \multirow[t]{5}{*}{$2(172)$} & med & 23 & 62 & 39 & 1.27 & 58 & 0.4 & 0.04 & - & 0.02 & - & - & 98 \\
\hline & & $\min$ & 6 & 48 & 20 & 0.01 & 17 & 0.01 & 0.01 & - & 0.02 & - & - & - \\
\hline & & $\max$ & 105 & 77 & 53 & 36 & 65 & 10 & 45 & - & 0.02 & - & - & - \\
\hline & & av & 27 & 62 & 38 & 11 & 52 & 0.68 & 1.18 & - & 0.02 & - & - & 98 \\
\hline & & SD & 15 & 3.3 & 3.2 & 14 & 11 & 1.14 & 7.01 & - & - & - & - & - \\
\hline & \multirow[t]{5}{*}{$4(22)$} & med & 32 & 60 & 27 & 56 & 17 & 0.39 & 0.08 & - & - & 0.02 & - & 100 \\
\hline & & $\min$ & 16 & 58 & 25 & 40 & 14 & 0.23 & 0.01 & - & - & 0.01 & - & - \\
\hline & & $\max$ & 38 & 64 & 32 & 66 & 27 & 0.56 & 0.32 & - & - & 0.02 & - & - \\
\hline & & av & 31 & 60 & 27 & 55 & 18 & 0.39 & 0.08 & - & - & 0.02 & - & 100 \\
\hline & & SD & 4.8 & 1.8 & 1.9 & 7.4 & 4.1 & 0.23 & 0.08 & - & - & - & - & - \\
\hline
\end{tabular}

sulfide aggregates with variable size (up to $600 \mu \mathrm{m}$ ), which may carry rounded oxide inclusions and are sometimes in sharp contact with surrounding silicate phases (Figs. 4xi, xii, 5e). Although all study areas present Type 2 sulfides, from the volcanic centres situated in the Usak basin, only Beydagi shows sulfide Type 3 and 5, whereas only Kula and Konya present sulfide Type 1 and 4, respectively.

Electron microprobe analysis of single mineral phases composing a multiphase sulfide inclusion confirms the above petrographic observations and SEM analysis. Sulfides belonging to Konya and to the volcanic areas of the UsakGüre basin (Beydagi, Elmadag, and Itecektepe) have compositions typical of the $\mathrm{Cu}-\mathrm{Fe}-\mathrm{S}$ system, whereas sulfides observed in Kula (intraplate OIB-like volcanism) extend into the $\mathrm{Cu}-\mathrm{Fe}-\mathrm{Ni}$ system as well (Fig. 7a, b). Sulfides from all areas present a range of compositions between pyrrhotite and cubanite-chalcopyrite (Type 2 and 5) hosted by different phenocrysts (mostly amphibole, pyroxene, and magnetite; Fig. 7a). Beydagi shows additional compositions between chalcopyrite (sometimes chalcocite) and close or equal to magmatic pyrite (Type 3), and Konya presents sulfides ranging from chalcopyrite to bornite compositions (Type 4). The latter types are only hosted by magnetite. In the case of Kula, Type 1 and some Type 2 sulfides are Ni-rich, ranging from pyrrhotite to pentlandite (Fig. 7b). A general decrease in the sulfide $\mathrm{Ni} / \mathrm{Cu}$ ratio versus the $\mathrm{Fe} / \mathrm{S}$ ratio can be noted, switching from Ni-rich sulfide phases (pentlandite) hosted by olivine to $\mathrm{Cu}$-rich (bornite) hosted by magnetite (Fig. 7c).
EPMA sulfide compositions often correspond to the variable nonstoichiometric atomic ratios of major components different from the typical expected base metal composition of the sulfide phase observed, resulting in intermediate values characteristic of a solid solution, mostly between two endmembers (e.g. cubanite, chalcopyrite, and bornite; Figs. 6, 7). In addition, in some cases sulfides are characterised by a sulfur deficiency, which, according to previous studies, may be a result of the replacement of sulfur by oxygen that is not directly measured by EPMA (e.g. Larocque et al., 2000; Keith et al., 1997). These latter cases usually show lower totals than those resulting from $\mathrm{Cu}$-rich Type 4 sulfide analysis (see Table 4 from Georgatou and Chiaradia, 2019).

A sulfide comparison for each area in terms of $\mathrm{Cu}$ and $\mathrm{Ni}$ contents, determined by EPMA, is shown in Fig. 8. Konya presents the most $\mathrm{Cu}$-rich sulfides (Type 4, $\mathrm{Cu}$ median $=56 \mathrm{wt} \%$ ) and Kula the most Ni-rich sulfides (Type 1 , Ni median $=4.2 \mathrm{wt} \%$ ). In the Usak basin Beydagi shows the most $\mathrm{Cu}$-rich sulfides (Type 3, Cu median $=32 \mathrm{wt} \%$ ), followed by Elmadag (Type 2, Cu median $=0.14 \mathrm{wt} \%$ ) and then by Itecektepe (Type 2, Cu median $=0.03 \mathrm{wt} \%$ ). In addition to $\mathrm{Cu}, \mathrm{Fe}, \mathrm{Ni}$, and $\mathrm{S}$, sulfides were also analysed for As, Se, Zn, Ag, and Au (see Table 2 in Supplement S2 for determination limits.). For all locations $\mathrm{As}$ and $\mathrm{Se}$ are generally lower than $0.1 \mathrm{wt} \%$. Zn concentrations were obtained only for Konya and Kula, showing, for Type 2 sulfides, $\mathrm{Zn}$ median $=0.03 \mathrm{wt} \%$ and $0.04 \mathrm{wt} \%$, respectively. Out of $503 \mathrm{Ag}$ and $196 \mathrm{Au}$ sulfide measurements obtained, only 

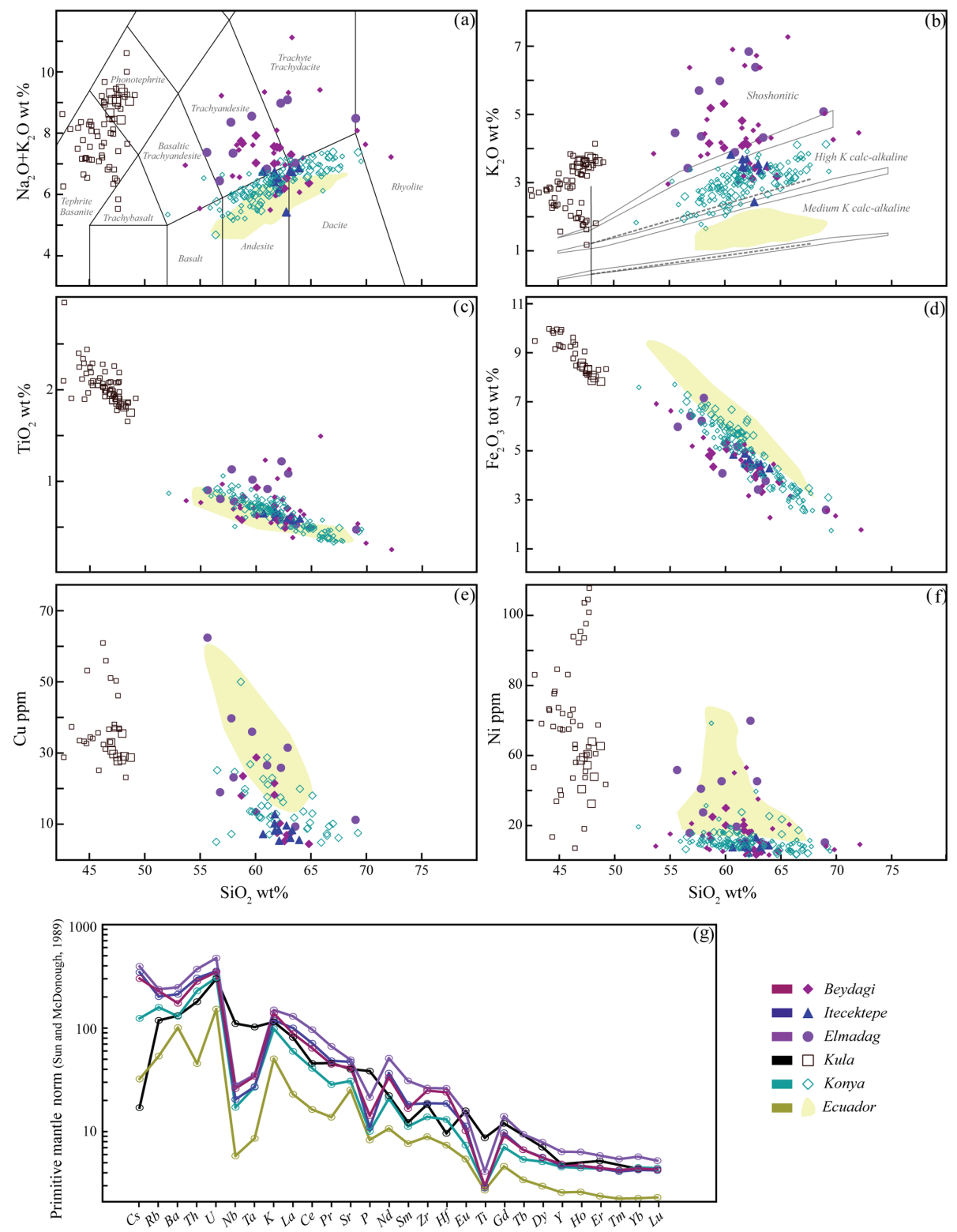

Figure 3. Major (a-d) and trace (e-h) element variations with $\mathrm{SiO}_{2}$ for the different study areas, illustrated by a different shape and colour. Smaller size symbols correspond to datasets obtained from other studies (Beydagi - Karaoğlu et al., 2010; Kula - Alici et al., 2002; Aldanmaz, 2002; Aldanmaz et al., 2015; Dilek et al., 2010; Ercan et al., 1983; Konya - Temel et al., 1998; Korkmaz et al., 2017). For comparison purposes whole rock chemistry from Ecuador has been illustrated as a field in the graphs (a-f). Spider graph (g) showing the solid mean trace element distribution for the different study areas. For the dataset, see Tables 1-3 from Georgatou and Chiaradia (2019).

82 and 31 values, respectively, resulted in concentrations above the detection and/or determination limit. Ag varies between $0.01 \mathrm{wt} \%$ and $0.07 \mathrm{wt} \%$ with a maximum amount of $0.11 \mathrm{wt} \%$ (in Konya), whereas Au is higher, showing higher values in the Usak-Güre basin (Au median $=0.14 \mathrm{wt} \%$ $0.24 \mathrm{wt} \%$ ) compared to the rest (Au median $=0.04 \mathrm{wt} \%$ $0.05 \mathrm{wt} \%)$. These unusually high sporadic values of $\mathrm{Ag}$ and Au have been attributed by previous studies to the clustering and nugget effects of noble metals (e.g. Savelyev et al., 2018; Zelenski et al., 2017; Holwell et al., 2015; Holwell and Mc-
Donald, 2010). A possible Au nugget occurrence is shown in Fig. 4viii for Type 3 sulfides of Beydagi. Although the phase is too small $(<0.5 \mu \mathrm{m})$ to obtain quantitative values by EPMA, detectable Au was measured by SEM near and on this high-reflectance micro-phase.

Since sulfide inclusions of all types are composed of more than one mineral phase (e.g. pyrrhotite and chalcopyrite), the sulfide composition data are presented and discussed in two different ways: (a) as individual microprobe measurements of mineral phases within each multiphase sulfide type from 


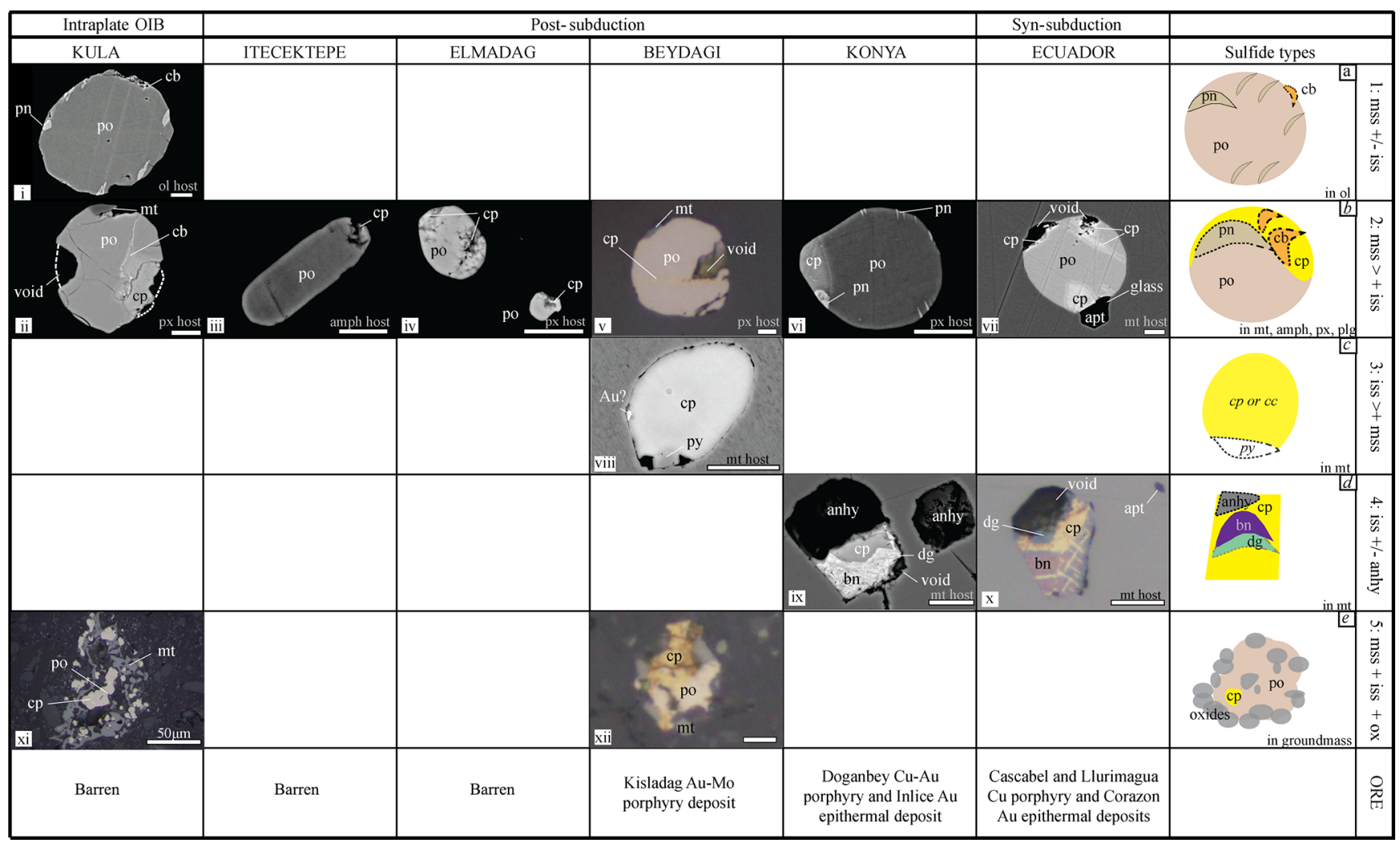

Figure 4. Sulfide types observed in the different study areas characterised by diverse geodynamic settings. The abbreviations stand for the following: pyrrhotite - po, pentlandite - pn, chalcopyrite - cp, chalcocite - cc, cubanite - cb, pyrite - py, bornite - bn, digenite - dg, anhydrite - anhy, apatite - apt, magnetite - mt, monosulfide solid solution - mss, and intermediate solid solution - iss. The scale bar corresponds to $5 \mu \mathrm{m}$ unless stated otherwise.

the different study areas (Table 1, Figs. 7, 8) and (b) as bulk compositions of the sulfide inclusion reconstructed by considering the modal abundance (area \%) and the EPMA concentrations for each phase composing the multiphase sulfide (see Table 2, Figs. 9 and 10, and examples of the reconstruction methods in Supplement S2).

Calculating the area percent occupied by each mineral composing the sulfide in the two-dimensional space (and therefore the mss/iss initial proportions) allows us to obtain indirect quantitative information on the initial metal contents of the silicate melt from which the sulfide melt was exsolved in the different study areas. This is because the areas characterising the mss and iss phases are proportional to the metal amounts that have partitioned into these phases. Whereas this approach may yield biased results due to cut effects, crystal orientation and other limitations of this method (see Supplement S2) averaged out over a large number of sulfide inclusions, so we think we have obtained a significant 1st-order estimate. The mean proportions of mss and iss in area percent are shown in the box plot in Fig. 9 and Table 2. The mss area percent $(\mathrm{mss} /(\mathrm{mss}+$ iss $) \cdot 100)$ and 2 standard errors for each study area are as follows: Kula $(82.0 \pm 7.4 \%)$, Itecektepe $(84.8 \pm 4.9 \%)$, Elmadag $(86.9 \pm 4.8 \%)$, Beydagi
$(86.9 \pm 3.2 \%)$, and Konya $(88.1 \pm 2.6 \%)$. A reconstruction of the bulk mss and iss in area (\%) composition of the sulfides was also realised in this study for the case of Ecuador for comparative purposes, resulting in an mss area percent of $82.0 \pm 4.8$. When Type 2 sulfides from all investigated areas for a total of 126 sulfides are considered together, all study areas present similar proportions of Fe-rich mss $(84.2 \%)$ and $\mathrm{Cu}$-rich iss $(15.7 \%)$ phases within error $(2 \mathrm{se}= \pm 2.2)$.

\section{Discussion}

\subsection{Sulfide melt evolution}

The evolution of sulfide melt has been studied through experiments considering sulfide globules as closed systems that differentiate with decreasing $T$ (e.g. Kullerud et al., 1969; Cabri, 1973; Naldrett and Gasparrini, 1971; Cabri, 1973; Craig and Scott, 1974; Tsujimura and Kitakaze, 2004; Holwell and McDonald, 2010; Naldrett, 2013, and references therein). Nonetheless, there is difficulty to correlate the different phase stability fields for the complete range of temperatures, i.e. $1200-100^{\circ} \mathrm{C}$. This is due to the fact that the $\mathrm{Fe}-\mathrm{Ni}-\mathrm{Cu}-\mathrm{S}$ system is a complex system characterised by 
Table 2. Summary composition of 100 reconstructed sulfides belonging to different sulfide types ( $N$ is the number of sulfides reconstructed) observed in every study area except Itecektepe and Elmadag where the Cu-rich phase was too small to analyse with the EPMA. The empty cells (-) correspond to a lack of measurement either because it was below the determination limit or not measured, and the term med accounts for the median (wt \%) values. For the complete dataset (including mss/iss area \% of Itecektepe and Elmadag), see Table 5 at https://doi.org/10.6084/m9.Figshare.8230787.

\begin{tabular}{|c|c|c|c|c|c|c|c|c|c|c|c|c|c|c|c|c|}
\hline \multirow[t]{2}{*}{ Area } & \multirow[t]{2}{*}{ Type $(N)$} & \multicolumn{2}{|c|}{ Whole rock med } & \multicolumn{3}{|c|}{ Area med \% } & \multicolumn{10}{|c|}{ EPMA med wt \% reconstruction } \\
\hline & & $\mathrm{Cu}$ ppm & $\mathrm{SiO}_{2}$ & mss & iss & void & $S$ & $\mathrm{Cu}$ & $\mathrm{Fe}$ & $\mathrm{Ni}$ & As & $\mathrm{Se}$ & $\mathrm{Zn}$ & $\mathrm{Ag}$ & $\mathrm{Au}$ & Tot \\
\hline \multirow[t]{2}{*}{ Beydagi } & $2(1)$ & 17.85 & 58.67 & 95.5 & 4.5 & 16.7 & 38.77 & 0.69 & 56.67 & 0.73 & - & - & - & - & 0.08 & 97 \\
\hline & $3(8)$ & 17.85 & 58.67 & 34.5 & 65.5 & 2.8 & 39.53 & 23.02 & 34.24 & 0.05 & 0.02 & 0.11 & - & 0.02 & 0.09 & 97 \\
\hline \multirow[t]{3}{*}{ Kula } & $1(4)$ & 28.8 & 47.42 & 99.5 & 0.5 & 0 & 37.84 & 0.1 & 55.35 & 4.42 & 0.05 & - & - & - & 0.03 & 99 \\
\hline & $2(25)$ & 28.8 & 47.42 & 88.7 & 11.2 & 0.7 & 37.93 & 2.57 & 56.66 & 0.73 & 0.04 & - & 0.02 & 0.02 & 0.03 & 99 \\
\hline & $5(8)$ & 29 & 47.64 & 86.8 & 13.1 & - & 36.03 & 3.46 & 57.3 & 1.03 & 0.04 & 0.02 & 0.02 & 0.01 & - & 98 \\
\hline \multirow[t]{2}{*}{ Konya } & $2(26)$ & 11.71 & 61.27 & 89.5 & 10.8 & 0.4 & 38.66 & 2.73 & 56.78 & 0.11 & 0.03 & 0.03 & 0.03 & 0.03 & 0.02 & 98 \\
\hline & $4(8)$ & 12.68 & 61.82 & 0 & 100 & 21.2 & 28.31 & 48.44 & 23.09 & 0.02 & 0.02 & 0.02 & 0.04 & 0.04 & - & 99 \\
\hline \multirow[t]{2}{*}{ Ecuador } & $2(10)$ & 19 & 62.27 & 78.5 & 21.5 & 16.9 & 37.7 & 6.04 & 53.47 & 1.71 & 0.02 & - & - & - & - & 98 \\
\hline & $4(10)$ & 32 & 59.66 & 0 & 100 & 5.65 & 28.09 & 51.71 & 21.05 & 0.37 & 0.11 & - & - & - & - & 100 \\
\hline
\end{tabular}

a number of solid solutions and unquenched phases. In addition, the mineral assemblage composing the sulfides depends, among other factors $\left(f \mathrm{O}_{2}\right.$ and $\left.f \mathrm{~S}_{2}\right)$, on the initial metal budget of the silicate melt and therefore on the metal contents of the exsolving sulfide melt, as well as on the $P$ and $T$ conditions under which this melt solidifies. A compilation of isothermal sections of the $\mathrm{Cu}-\mathrm{Fe}-\mathrm{S}$ system resulting from a number of experimental studies realised at different temperatures is presented in Fig. 10. For this study it is important to note at which approximate temperature intervals mineral phases can coexist, and therefore a summary of the experimental findings, only focused on the mineral phases observed in this study, is presented below.

The general agreement is that above $1200{ }^{\circ} \mathrm{C}$ the system is composed of a metal-rich $(\mathrm{Cu}, \mathrm{Au})$ liquid and a sulfurrich $(+\mathrm{Fe}, \mathrm{Ni})$ liquid (Craig and Kullerud, 1969). An Fe, $\mathrm{Ni}$-rich, Cu-poor monosulfide solid solution (mss) and a Cu, Au-rich, Ni-poor intermediate solid solution (iss) exsolve at around $1192^{\circ} \mathrm{C}$ (Jensen, 1942) and $960^{\circ} \mathrm{C}$ (Kullerud et al., 1969), respectively (Fig. 10a-b and c). The pair mss-iss is stable only starting from 935 and until $590^{\circ} \mathrm{C}$ (Fig. 10ce), below which these two phases cannot coexist. At around $930^{\circ} \mathrm{C}$ a high-temperature bornite solid solution (bnss-h) and iss become stable (Fig. 10c). With further cooling $\left(\sim 610^{\circ} \mathrm{C}\right.$; Fig. 10e) the mss converts to pyrrhotite (po) through the exsolution of a high-temperature pentlandite (pn-h) (e.g. Stone et al., 1989). Subsequently, at $590^{\circ} \mathrm{C}$ the iss unmixes into chalcopyrite (cp) and cubanite (cb) (Fig. 10f; e.g. Yund and Kullerud, 1966). Pyrite (py) appears at $743^{\circ} \mathrm{C}$ and becomes stable with iss at $739^{\circ} \mathrm{C}$ and with cp at $600^{\circ} \mathrm{C}$ (Fig. 10e). The pair cp-py coexists until at least $200^{\circ} \mathrm{C}$ (Craig and Scott, 1974). A low-temperature pentlandite (pn) appears at $610^{\circ} \mathrm{C}$ and becomes stable with $\mathrm{cp}$ at $572^{\circ} \mathrm{C}$. Finally, the bnss-h breaks down to a chalcocite (cc-bnss) and digenite (dg-bnss) bnss pair at $430^{\circ} \mathrm{C}$ (Fig. 10 g). At $334^{\circ} \mathrm{C}$ pyrrhotite becomes stable with chalcopyrite, and with further cooling at $330^{\circ} \mathrm{C}$ the digenite-bnss pair breaks down to digenite and bornite (bn; Fig. 10g-h).

Two main stages of sulfide evolution were observed in this study, confirming the experimental temperature range windows for specific mineral pairs as well as conclusions from previous research (Hattori, 1996; Parat et al., 2011; Du et al., 2014; Agangi and Reddy, 2016). The first stage accounts for the more primitive sulfide types (Type 1 and 2) including mss-rich \pm iss and mss + iss sulfide melt, now represented by compositions (shown from individual mineral analysis in Fig. 7 and reconstructed area compositions in Fig. 10) close to pyrrhotite ( \pm pentlandite, cubanite) and pyrrhotite + chalcopyrite ( \pm cubanite), respectively. Their shape (round-ellipsoidal) and host mineral (olivine for Type 1 and amphibole, pyroxene, plagioclase, and magnetite for Type 2) confirm their origin as $\mathrm{Fe}-\mathrm{Ni}$-rich $( \pm \mathrm{Cu}$ ) sulfide melts. The second stage consists of Type 4 sulfides, characterised by an iss-only and $\mathrm{Cu}$-rich sulfide liquid (as all the $\mathrm{Ni}$ has been exhausted), which now comprises chalcopyrite and bornite ( \pm digenite). This sulfide type occurs only within Fe oxides, mostly in Ti-rich magnetite displaying occasional ilmenite exsolution lamellae. Their angular shape indicates that the solution was trapped initially as a $\mathrm{Cu}$-rich liquid (Chang and Audétat, 2018) which solidified into an iss following the host mineral crystallisation planes and later unmixed (see also Georgatou et al., 2018; Holwell et al., 2015). In addition to the relatively low temperature ranges compared to the first stage sulfides $\left(<330^{\circ} \mathrm{C}\right.$; see Fig. 10$)$, other petrographic and compositional arguments for considering this a later stage are the following: (i) the unique occurrence in magnetite, a late crystallising mineral relative to olivine and pyroxene (hosting the first stage sulfide Type 1 and 2), and (ii) the more common occurrence of voids and/or vesicles around the $\mathrm{Cu}$-rich sulfides accounting for higher mean por- 

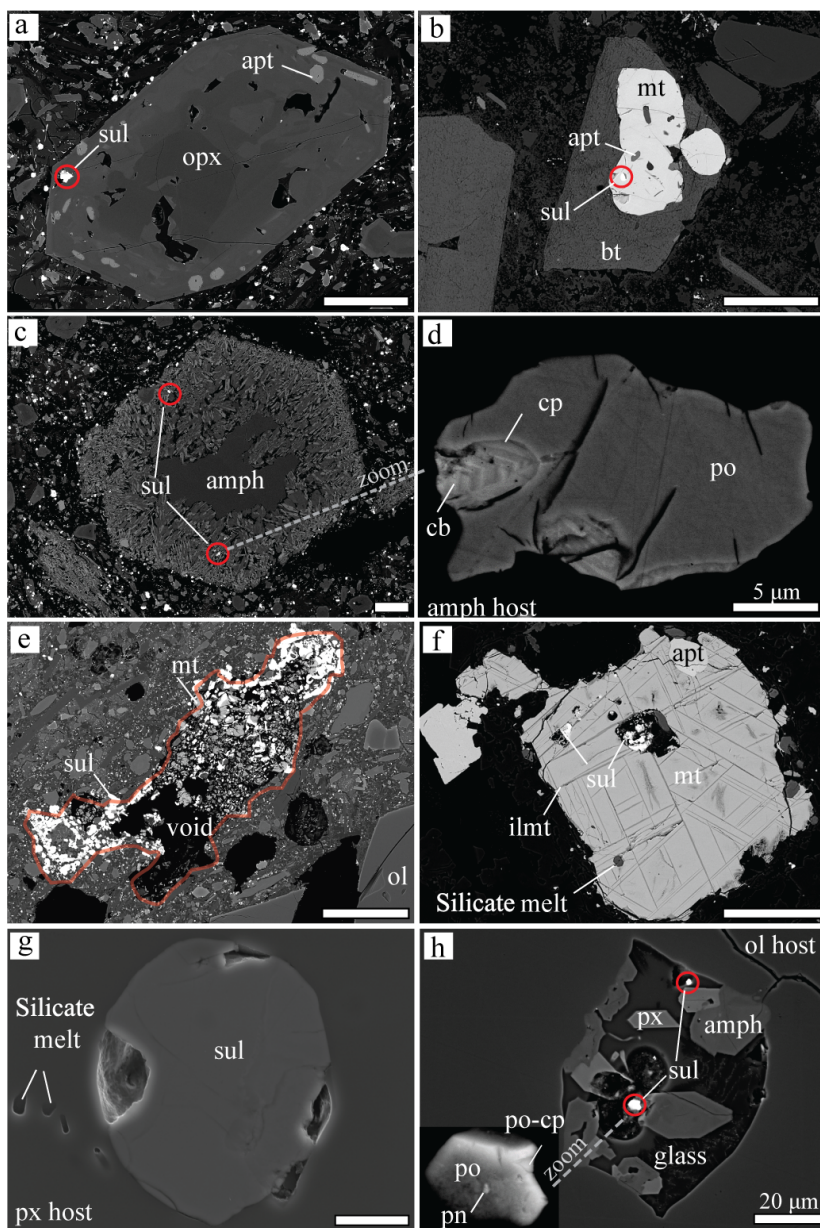

Figure 5. Backscattered electron (BSE) (a-f, h) and secondary electron (SE) (g) microphotographs of sulfides, their host, and accessory mineral phases. Important things to note: (a) the common occurrence of apatite inclusions observed together with the sulfide and hosted by the same mineral (px in $\mathbf{a}$ and $\mathrm{mt}$ in $\mathbf{b}, \mathbf{f}$ ); (b) the lack of sulfides in the biotite phenocrysts, even in the cases in which the biotite itself includes a magnetite that hosts sulfides; (c) the usual sulfide presence in the amphibole destabilised rim, where amphibole is being replaced by clinopyroxene, plagioclase, and rhönite, characterising the Kula volcano (also seen by Grutzner et al., 2013); (d) resorbed sulfide found in amphibole in (c) showing a rapid unmixing of the $\mathrm{cp}-\mathrm{cb}$ (iss); (e) unusually big (up to $600 \mu \mathrm{m}$ ) sulfide aggregate composed of mostly $\mathrm{Cu}$-poor sulfides, magnetite, and micro-sized silicates found in Kula; (f) partly dissolved sulfide hosted by magnetite that shows ilmenite exsolution lamellae; (g) a trail of bubbles of the silicate melt and vesicles associated with the sulfide; and (h) daughter sulfide $(<0.5 \mu \mathrm{m})$ composed mostly of po found in recrystallised melt inclusion hosted by olivine, as observed in Kula. For abbreviations, see the legend in Fig. 4. The scale bar corresponds to $100 \mu \mathrm{m}$ unless stated otherwise.

tions of the inclusions (up to 23 area $\%$, with up to 19 area $\%$ for Type 4 and 14 area $\%$ for Type 3; see Fig. 6 and Table 5 in Georgatou and Chiaradia, 2019) compared to Type 2 sulfides $(<5$ area \%). The contact between each sulfide inclusion and

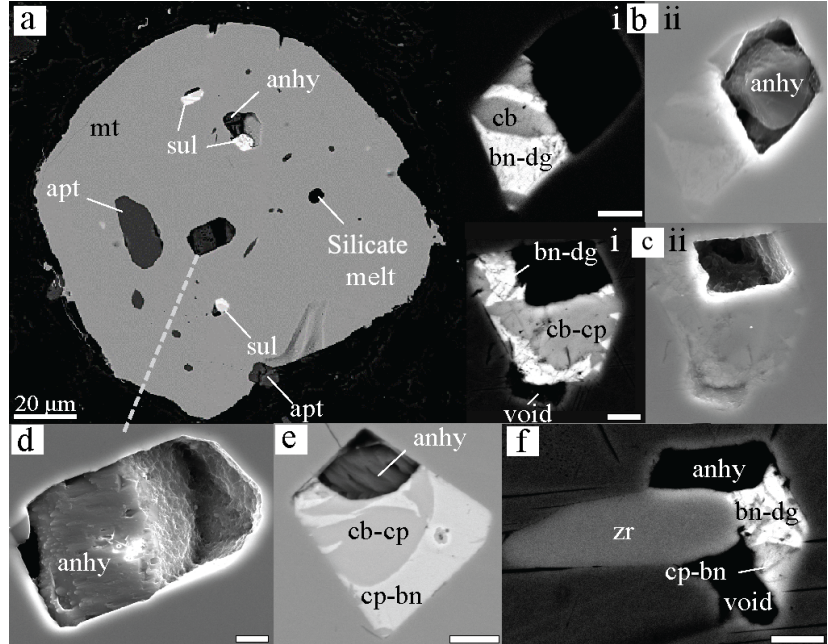

Figure 6. BSE (a, b-i, c-i, e, f) and SE (b-ii, c-ii, d, e) microphotographs of anhydrite occurrences in magnetite phenocrysts, as individual phases or found together with $\mathrm{Cu}$-rich sulfides and occasionally with zircons. Apatite and silicate melts are often hosted by the same magnetite phenocrysts as well. Note that the anhydrite (b$\mathbf{i}, \mathbf{f})$ in BSE is not visible unless seen in SE (b-ii); it can be partly (d, e) or completely (c) dissolved. In panel (e) BSE and SE imagining have been merged in order to make both sulfide and sulfate, respectively, visible. For abbreviations, see the legend in Fig. 4. The scale bar corresponds to $2 \mu \mathrm{m}$ unless stated otherwise.

these vesicles is smooth, indicating that these voids could account for a pre-existing fluid phase which exsolved from the silicate melt before entrapment in the magnetite crystal (Table 2).

Sulfide Type 3 and 5 are more difficult to interpret. Type 3 presents both ellipsoidal and rectangular shapes, indicating entrapment as a liquid. The temperature range that corresponds to the mineral assemblage of chalcopyrite ( \pm chalcocite $)+$ pyrite is $600-200^{\circ} \mathrm{C}$, suggesting a later timing than the first-stage sulfides. Finally, Type 5 sulfide aggregates are similar to the first-stage sulfides (Type 2) and seem to have originated from an mss- and Fe-rich system, producing immiscibility textures of the rounded oxide inclusions into the pyrrhotite, which have later aggregated with silicates.

In this study, no early and late sulfides cohosted by the same mineral were observed. This suggests two distinct sulfide saturation stages, during which the system has to undergo magnetite crystallisation to reach the second stage. However, it is still not clear whether these stages are indeed distinct and independent of one another or if they may directly follow one another through a continuous process of sulfide saturation, whose products change chemistry due to the chemical evolution of the melt. Nonetheless, according to the sulfide types observed in these two stages, the $\mathrm{Ni} / \mathrm{Cu}$ (proxy for mss/iss) decreases with magmatic evolution (Fig. 7c), starting from an mss-rich sulfide melt (Type 1), 


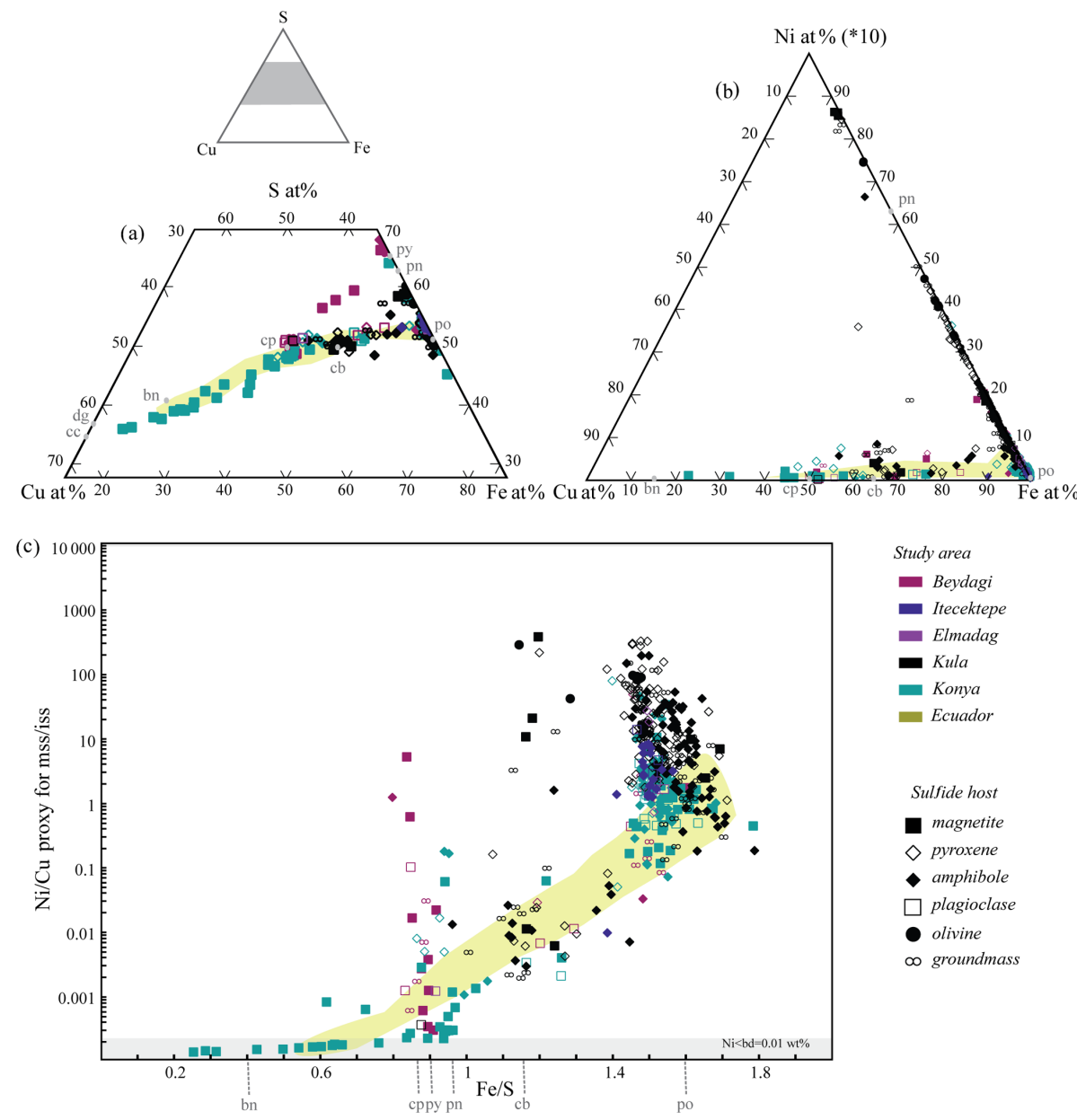

Figure 7. Sulfide composition in the $\mathrm{Cu}-\mathrm{Fe}-\mathrm{S}$ system and $\mathrm{Ni}-\mathrm{Fe}-\mathrm{Cu}$ from individual mineral analyses by EPMA. The colour shows the study area, and the shape indicates the host mineral in which magmatic sulfides were found. Note the progressive $\mathrm{Ni} / \mathrm{Cu}$ depletion as we switch from more mafic suites (e.g. Kula) and early crystallising host minerals (olivine, pyroxene, and amphibole) to more evolved (e.g. Konya) and later crystallising mineral phases (magnetite). The grey fields correspond to analyses that resulted in Ni or Cu below the determination limit equal to $0.01 \mathrm{wt} \%$ that for discussion purposes are shown here. For the dataset, see Table 4 at https://doi.org/10.6084/m9.Figshare.8230787.

followed by an mss and iss melt (Type 2 and 5), and finally (and uniquely for some settings) by iss-rich, iss-only sulfides (Type 3 and 4). Although this decrease in $\mathrm{Ni} / \mathrm{Cu}$ has been noted previously by other researchers (e.g. Hattori, 1996; Du et al., 2014; Keith et al., 2017; Savelyev et al., 2018), for the early sulfides, until now there has not been a systematic study of the later-stage, iss-only sulfides. The reason for this is most likely the fact that the majority of past studies on sulfides have focused on silicate mineral separates in order to be able to locate and analyse the bulk chemistry of entrapped sulfides. This not only prevents necessary observations on textural mineral relations but also the study of nontransparent to opaque minerals, which, as was shown here, host $\mathrm{Cu}$-rich and iss-only sulfides.

\subsection{Textural and compositional comparison of sulfides within the western Anatolia study areas}

Volcanic rocks from all study areas contain sulfides and therefore have reached magmatic sulfide saturation at some stage during the lifespan of the magmatic system; however, there are significant textural and compositional differences, which are described below.

\subsubsection{Kula volcanic field}

In Kula, where rocks correspond to more primitive compositions (tephrites-basanites to phonotephrites), we observe sulfide Type 1,2 , and 5 , representing the most primary $\mathrm{Ni}$ rich and $\mathrm{Cu}$-poor magmatic products resulting from an initial, mostly mss-rich sulfide melt exsolving from a silicate melt. These sulfide types are similar to those found in midocean ridge basalts (MORBs; e.g. Patten et al., 2012; Keith 


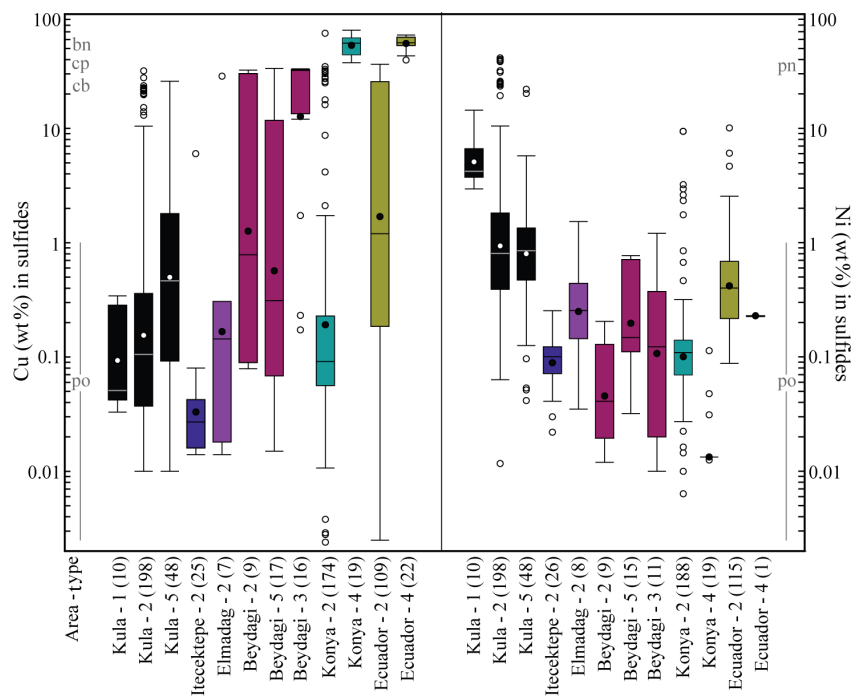

Figure 8. Box plot comparison of the $\mathrm{Cu}$ and $\mathrm{Ni}$ content (wt \%) resulting from individual mineral analyses measured by EPMA for the different sulfide types characterising each study area. The central box is in the middle $50 \%$ of the data (total number of measurements considered is noted in parenthesis on the $x$ axes). The line and dots in the box represent the median and mean value for each box and sulfide type, respectively (see values in Table 1). The outliers are further than 1.5 (the 75th percentile is on top of the box, and the 25th percentile is at the bottom of the box), and the whiskers are the extreme values that are not outliers. Note that only Beydagi, Konya, and Ecuador which, are the three areas associated with porphyry deposits, display the highest in $\mathrm{Cu}$ values of Type 3 and 4 sulfides. The stoichiometry of common sulfide mineral phases has been depicted for $\mathrm{Cu}$ and $\mathrm{Ni}$ (wt \%) contents according to mindat.org. For the dataset, see Table 4 at https://doi.org/10.6084/m9.Figshare.8230787.

et al., 2017; Savelyev et al., 2018, and references therein) and represent the first stage of sulfide saturation. From textural evidence, e.g. decompression rims in amphibole (Fig. 5c), complex textures of cubanite-chalcopyrite resulting from the rapid unmixing of iss due to temperature drop (Fig. 5d; Type 3 ), and the intact sulfide aggregates found in the groundmass (Fig. 5e; Type 5), the magma in Kula seems to have ascended rapidly from depth (e.g. Tokçaer et al., 2005). This implies a short residence time in the crust, which in turn explains the minimum crustal contamination (e.g. Dilek and Altunkaynak, 2007; Alici et al., 2002) and the mafic rock composition.

\subsubsection{Konya}

For the case of Konya, the products of which range from andesites to dacites, the sulfide types found (Type 2 and 4) represent both stages of sulfide saturation and are less primitive than the ones seen in Kula, with little or no pentlandite present and always a $\mathrm{Cu}$-rich phase (chalcopyrite \pm bornite). This suggests that the mss- and iss-rich sulfide melt started exsolving from the silicate melt at a later stage of magmatic

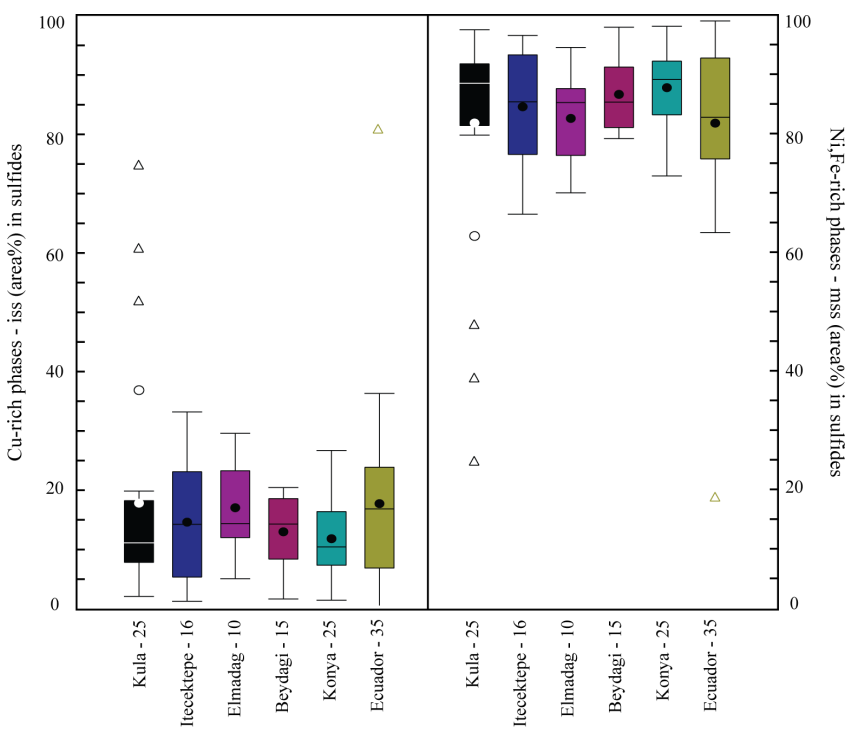

Figure 9. Box plot comparison of the Cu-rich phase (chalcopyrite $=$ iss) and Ni-rich phase (pyrrhotite \pm pentlandite $=$ mss) proportions (area \%) composing Type 2 sulfides, calculated by ImageJ(C) 1.38 software analysis for each study area $(-\mathrm{N}$ of sulfides reconstructed). Average, mean, and median values are represented in the graph the same as in Fig. 8. For the dataset, see Table 5 at https://doi.org/10.6084/m9.Figshare.8230787.

evolution, when the melt was already depleted in $\mathrm{Ni}$ and already had a higher amount of iss available compared to Kula. In fact, the Type 4 iss-only sulfide melt of Konya (representing the second to later stage of sulfide saturation) has sequestered $\mathrm{Cu}$ more successfully than at any other location investigated.

Konya is the unique example in this study presenting anhydrite inclusions in contact with a sulfide phase or hosted by the same magnetite phenocryst as the sulfide inclusion (Fig. 6). The occurrence of anhydrite either in contact or along with $\mathrm{Cu}$-rich sulfide phases has been mentioned in the past (e.g. Hattori, 1993; Audétat and Pettke, 2006) and has been suggested to indicate a rapid drop of $f \mathrm{O}_{2}$ in the system from the sulfate $(>\mathrm{NNO}+1)$ to sulfide stability field $(<\mathrm{NNO})$, allowing the magma to contain both reduced and oxidised forms of sulfur (Wilke et al., 2011). From experimental constraints for a water-saturated system at $150-400 \mathrm{MPa}$ and $1 \mathrm{wt} \% \mathrm{~S}$ added, anhydrite can coexist with pyrrhotite for $f \mathrm{O}_{2}=\mathrm{NNO}+1$ at $700^{\circ} \mathrm{C}$, for $f \mathrm{O}_{2}=$ $\mathrm{NNO}+1.5$ at $800^{\circ} \mathrm{C}$, and for $f \mathrm{O}_{2}=\mathrm{NNO}+2.5$ at $950^{\circ} \mathrm{C}$ (Parat et al., 2011, and references therein). Therefore, the occasional occurrence of anhydrite in these second-stage sulfides (Type 4) would indicate higher temperatures. In addition, the coexistence of sulfide inclusions, anhydrite, apatite, and silicate melt within the same magnetite crystal would also indicate higher temperatures and a rather magmatic origin of those sulfides. However, in this study the sulfide mineral phases with which anhydrite coexists are $\mathrm{Cu}$-richer and 

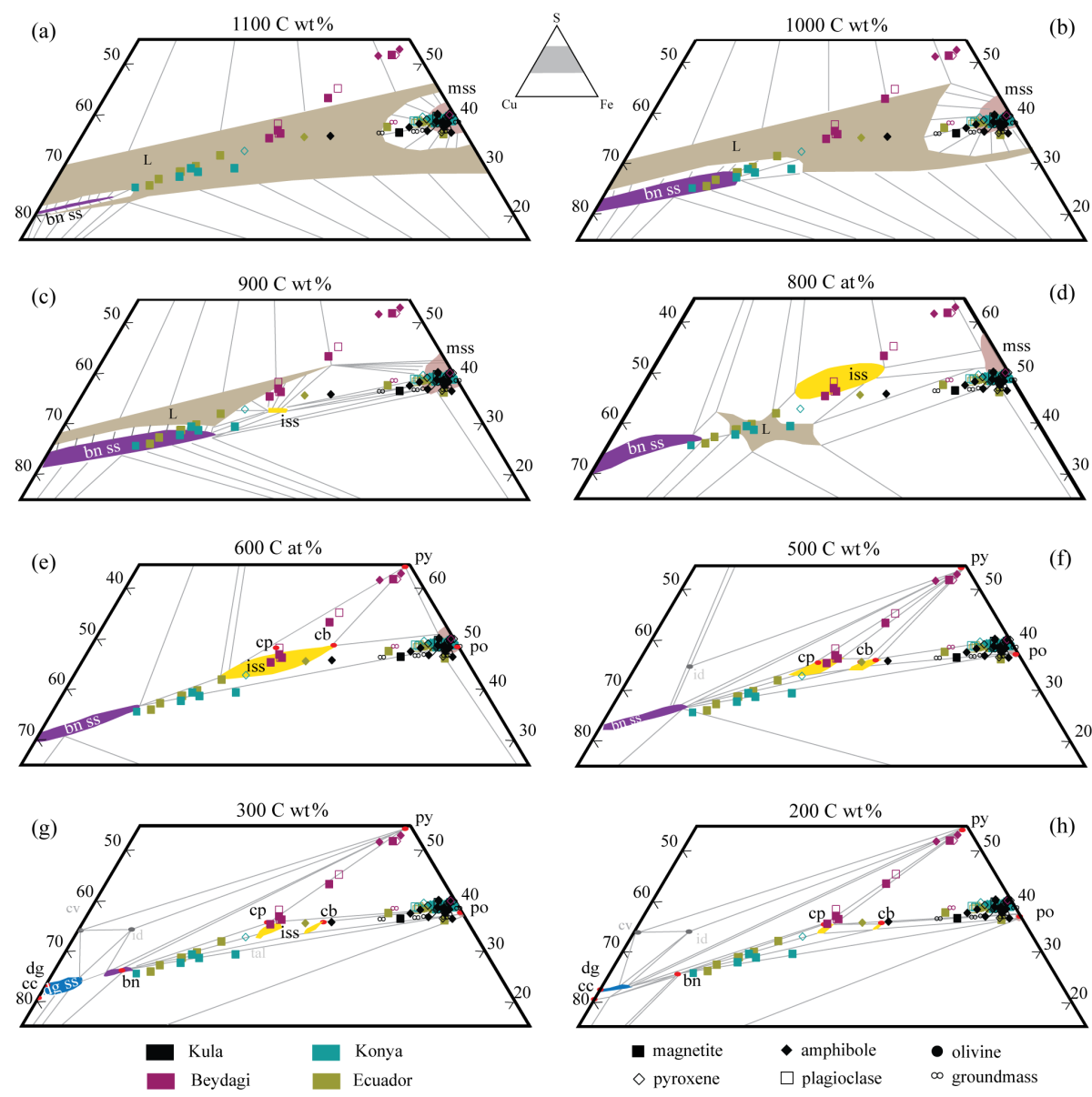

Figure 10. Ternary isothermal sections through the central part of the $\mathrm{Cu}-\mathrm{Fe}-\mathrm{S}$ system according to and modified from (a, b, c) Kullerud et al. (1969), (d) Tsujimura and Kitakaze (2004), (e) Cabri (1973), (f, h) Yund and Kullerud (1966), and (g) Craig and Scott (1974). The stability fields and phase relations at different temperatures are shown for the following: sulfide liquid - L (brown), bornite solid solution bnss (purple), monosulfide solid solution - mss (pink), intermediate solid solution - iss (yellow), and digenite solid solution - dgss (blue). The data shown correspond to the bulk (area \%) reconstructed sulfide compositions hosted by the different phenocrysts and/or groundmass (shape) observed in every study area (colour). For the dataset, see Table 5 at https://doi.org/10.6084/m9.Figshare.8230787.

S-poorer (chalcopyrite + bornite \pm digenite) than pyrrhotite and are stable at higher $f \mathrm{O}_{2}$ conditions and lower $T$. In addition, the system is not expected to already be watersaturated since we would expect that the metals partition into the fluid phase in such a case, resulting in hydrothermal rather than magmatic sulfides. Therefore, the temperature ranges in which anhydrite is stable can differ.

\subsection{Usak-Güre basin}

Beydagi shows slightly more enriched (though similar within error) $\mathrm{Cu}$ values in Type 2 sulfide $(\mathrm{Cu}$ median $=0.3 \mathrm{wt} \%)$ than Elmadag $(\mathrm{Cu}$ median $=0.14 \mathrm{wt} \%)$ and Itecektepe $(\mathrm{Cu}$ median $=0.03 \mathrm{wt} \%)$. Additionally, the area $(\%)$ of the $\mathrm{Cu}$ phase iss of Type 2 sulfides found in Elmadag (17.2 \pm 4.8 ), Itecektepe (14.7 \pm 4.9$)$, and Beydagi $(13.1 \pm 3.2)$ is similar. However, although in terms of bulk chemistry there are not major differences between the three volcanic centres (mostly andesites to trachyandesites), Beydagi is the only volcanic centre within the Usak basin which is characterised by two other sulfide types (Type 3 and 5) and at the same is the only mineralised volcanic centre. Implications regarding the ore fertility of these systems will be discussed in the following section. Relative to the other investigated areas of western Anatolia, sulfides in Beydagi show no pentlandite but in some cases present chalcopyrite ( \pm chalcocite) coexisting with pyrite. This suggests that the iss-rich exsolving sulfide melt was $\mathrm{Cu}$-rich relative to $\mathrm{Kula}$ but $\mathrm{Cu}$-depleted relative to Konya.

\subsection{Comparison of sulfide textures and compositions between western Anatolia systems and Ecuador}

Various Miocene large $\mathrm{Cu}-\mathrm{Mo} \pm \mathrm{Au}$ porphyry deposits (e.g. Junín-Llurimagua $\mathrm{Cu}-\mathrm{Mo}$ deposit and the Cascabel $\mathrm{Cu}-\mathrm{Au}$ rich deposit) occur in the frontal arc of Ecuador. Available 
data on whole rocks indicate that mineralisation is spatially and temporally associated with high-Sr/Y porphyritic stocks (Schütte et al., 2012). Investigation of these rocks under a reflected petrographic microscope confirmed previous observations from Schütte et al. (2012) that the rocks contain abundant hydrothermal sulfides, rendering these samples inadequate for the scope of the present study. For this reason, Georgatou et al. (2018) investigated fresh volcanic rocks from the Quaternary arc of Ecuador. These are intermediate to felsic calc-alkaline magmatic rocks with high $\mathrm{Sr} / \mathrm{Y}$ values erupted through a crust with a thickness ranging from 50 to $70 \mathrm{~km}$ (Feininger and Seguin, 1983; Guillier et al., 2001). Such features are similar to those of magmatic systems typically associated with large porphyry $\mathrm{Cu}$ deposits (Loucks, 2014; Chiaradia and Caricchi, 2017), and the temporal and spatial proximity of Miocene deposits to the Quaternary arc rocks investigated lend support to the possibility that processes leading to the formation of porphyry-type deposits under the Quaternary arc of Ecuador could be currently ongoing. Therefore, the Quaternary arc rocks of Ecuador can be used as a proxy for a potentially fertile syn-subduction magmatic environment.

In the Quaternary volcanics, Georgatou et al. (2018) observed that magmatic sulfides occurred in all studied rocks (from basalt to dacite) of the volcanic arc as polymineralic inclusions composed of Fe-rich, $\mathrm{Cu}$-poor, and/or $\mathrm{Cu}$-rich phases, occurring mostly in Fe/Ti oxides and to a lesser extent in silicate minerals. Only sulfide Type 2 and 4 were observed in Ecuador, presenting a remarkable textural and compositional resemblance to the case of Konya. Rocks from both areas display first-stage (Type 1 and 2) and second-stage (Type 4) sulfide saturation. In particular, according to EPMA, in individual mineral analyses of 19 sulfides in Konya and 22 in Ecuador, $\mathrm{Cu}_{\max }$ ranges between $72 \mathrm{wt} \%$ and $66 \mathrm{wt} \%$, respectively.

Georgatou et al. (2018) suggested that the negative trend of $\mathrm{Cu}$ with magmatic differentiation (e.g. Keith et al., 1997; Chiaradia, 2014) observed in typical syn-subduction magmatic arcs is a result of a continuous $\mathrm{Cu}$ sequestration in magmatic sulfides. A similar $\mathrm{Cu}$ decrease with magmatic evolution is also observed in the areas studied here and characterised by post-subduction magmatic rocks, some of which are also associated with porphyry and epithermal-type deposits. This suggests that in both settings (syn-subduction and post-subduction) $\mathrm{Cu}$ and other chalcophile metals behave compatibly during magmatic evolution and confirms that these metals are lost on the way to the surface.

\section{Implications for ore formation}

Some of the most discussed fertility issues of magmatic systems producing a porphyry deposit involve (i) metal and volatile contents in the primary magma (e.g. Core et al., 2006), (ii) metal and volatile element content changes dur- ing evolution of the primitive magma to the intermediate felsic compositions typically associated with porphyry-type deposits (e.g. Richards and Kerrich, 2007), (iii) magma volume and duration of magmatic-hydrothermal activity (e.g. Chiaradia and Caricchi, 2017), and (iv) the efficiency of preconcentration processes of chalcophile and siderophile elements in sulfide-rich zones (e.g. Nadeau et al., 2010).

Fertility issues (iii) and (iv) above have been addressed by various studies. Cline and Bodnar (1991) and more recently Chiaradia and Caricchi (2017) and Chelle-Michou et al. (2017) have shown that there is a correlation between the size of the magma reservoir providing metals and fluids to the ore system and the size of the deposit and that the duration of the ore process might also play a role in this sense.

Sulfide pre-concentration in cumulates at depth and a later magmatic recycling through remelting and release of the metals back to the system has been suggested as a possibility by various studies (e.g. Richards, 2009; Lee et al., 2012; Audétat and Simon, 2012; Sillitoe, 2012; Wilkinson, 2013; Chiaradia, 2014; Jenner, 2017; Fontboté et al., 2017). However, further investigation to quantify the physicochemical conditions under which this recycling process may be possible or not is needed.

Below we discuss fertility issues (i) and (ii) above in the light of our data. For source fertility to play an important role in terms of metal budget, it would imply an obvious difference in the proportions of mss ( $\mathrm{Cu}$-poor) and iss ( $\mathrm{Cu}$-rich) composing the most primitive sulfides (Type 2) for the different study areas. This would be a result of different metal abundances in the initial silicate melt that would preferentially partition into either the iss (e.g. $\mathrm{Cu}, \mathrm{Au}$ ) or the mss (e.g. $\mathrm{Ni}, \mathrm{Fe}$ ), respectively. For example, the average area (\%) of the $\mathrm{Cu}$-rich iss phases in sulfide inclusions from Beydagi, Konya, and Ecuador, relative to the mss phases composing the same sulfide inclusions, should be larger compared to the area $(\%)$ of the iss phases in sulfide inclusions of Kula, Itecektepe, and Elmadag. This goes against the results found in this study, in which inclusions from all regions show similar relative proportions $(84.2$ and $15.7 ; 2$ standard errors $= \pm 2.2$ area $\%$ ) of $\mathrm{Ni}$-rich mss and $\mathrm{Cu}$-rich iss phases. These values are very similar to the mss-iss proportions of sulfides found in the Merapi volcano (mss $=81 \pm 7$ and iss $=19 \pm 7$, respectively; Nadeau et al., 2010). Also, according to the study carried out by Chang and Audétat (2018) on arc magmas of Santa Rita and Cherillos (New Mexico) using LA-ICP-MS, the more $\mathrm{Cu}$-rich iss mineral phases are $\leq 20$ vol \% relative to the $\mathrm{Cu}$-poor mss. A second argument that supports the contention of similar metal contents in the primitive magmas is that there are no significant differences in the $\mathrm{Cu}$ values of Type 2 sulfides for the individual EPMA analysis $(\mathrm{Cu}$ median $=0.03 \mathrm{wt} \%-1.3 \mathrm{wt} \%$; Table 1 and Fig. 8) or for the bulk area reconstructed compositions $(\mathrm{Cu}$ median $=0.69 \mathrm{wt} \%-6.04 \mathrm{wt} \%$; Table 2$)$ among the areas that present iss-only sulfides and are associated with porphyry deposits. This observation carries major implications, 
suggesting that independent of the geodynamic setting (subduction, post-subduction, and intraplate OIB-like volcanism) the initial metal abundances of the primitive magmas are approximately the same (see also Lee et al., 2012, for similar $\mathrm{Cu}$ contents in primitive arc basalts and MORBs).

Because $\mathrm{H}_{2} \mathrm{O}$ is incompatible, magma evolution from a primitive basaltic magma will result in increasing concentrations of $\mathrm{H}_{2} \mathrm{O}$ in the residual derivative magmas of intermediate to felsic composition until water saturation may be reached depending mostly on the depth at which magma evolution occurs (e.g. Kelley and Cottrell, 2009; Richards, 2011). It is likely that all magmatic systems have the potential to become saturated in $\mathrm{Cu}$-rich, iss-only sulfides after exhausting all the $\mathrm{Ni}$, as long as the system does evolve to intermediate felsic compositions while still not reaching water saturation conditions before sulfide saturation occurs. Based on the textural and chemical evidence from Konya, in particular the coexistence of vesicles indicating a preexisting gas phase in contact with Type 4 sulfides, we may be able to trace the transition from a sulfide-saturated system to a fluid-saturated system. Indeed, only the rather primitive rocks from Kula did not evolve enough in order to reach the second saturation stage.

An additional important factor in order to saturate sulfide $\mathrm{Cu}$-rich phases is magnetite crystallisation. Although it has already been pointed out as an important step for sulfide saturation in general (e.g. Metrich et al., 2009; Jenner et al., 2010) in this study we show that magnetite crystallisation does not seem necessary for the saturation of any sulfide type but is systematically associated with the issrich (chalcopyrite-pyrite) and iss-only (chalcopyrite-bornite and/or digenite) $\mathrm{Cu}$-rich sulfide types (Type 3 and 4). Only rocks that have undergone magnetite crystallisation present $\mathrm{Cu}$-richer sulfides, with the exception of Kula as well as the cases of Elmadag and Itecektepe, the lavas of which do not include magnetite (Fig. 7). These three volcanic centres are not associated with any known economic deposit.

In contrast, Konya, Beydagi (Usak basin), and Ecuador are the only areas among those studied which present iss-only (Type 4) and iss-richer (Type 3) sulfides. The rocks in which these sulfide types are present correspond to more evolved lithologies $\left(\mathrm{SiO}_{2}>60 \mathrm{wt} \%\right)$ associated or potentially associated with economic deposits of the porphyry suite. It is noteworthy that this feature coincides with the fact that rocks from these areas are the only ones with iss-only (Type 4) and iss-richer (Type 3) sulfides. In particular, Type 4 sulfides (chalcopyrite-bornite \pm digenite) were observed in areas associated (Konya) or potentially associated (Ecuador) with porphyry $\mathrm{Cu}$ deposits (e.g. Konya-Doğanbey and EcuadorCascabel-Llurimagua-Junín). Beydagi, where Type 3 sulfides (chalcopyrite-pyrite) are seen, is associated with a porphyry Au deposit (Kişladağ). The above observation calls for further investigation since the presence of iss-rich and issonly sulfide types (like in cases 3 and 4) in felsic volcanic rocks, in particular in magnetite host minerals, could be used as a proxy for porphyry $\mathrm{Cu}$ - and porphyry Au-type deposits, respectively.

An additional significant implication based on the correlation between Type 3 and 4 sulfides high in $\mathrm{Cu}$ and ore deposits (Beydagi, Konya, and Ecuador), combined with the similar initial metal contents of the magmas of these areas, suggests an increase in the $\mathrm{Cu}$ contents of the sulfides and in the later hydrothermal ore fluid, which has not occurred in the other study areas. We argue that the later sulfide Type 3 and 4 (iss-rich and iss-only, hosted in magnetite) can help us to further understand the transition between a sulfidesaturated system and a fluid-saturated system. In addition, taking into consideration how porphyry deposits in subduction settings are generally $\mathrm{Cu}$-rich, whereas those found in post-subduction settings tend to be Au-rich (e.g. Sillitoe, 1993; Li et al., 2006; Richards, 2009), future sulfide trace element LA-ICP-MS analysis including precise $\mathrm{Au}, \mathrm{Ag}$, and PGE values (which constitute better markers for sulfide saturation identification; see Park et al., 2019, 2015; Cocker et al., 2015; Jenner, 2017; Mandon, 2017) could help distinguish the conditions of magma fertility for the different geodynamic settings. Finally, magmatic sulfide saturation will retain a certain number of chalcophile and siderophile elements and deplete the residual melt in them. Quantifying this metal loss is crucial in order to understand whether, for the sake of ore-forming processes, this loss is significant or not and may be compensated for by other more critical ingredients like an increase in volatiles and magma volumes (Chiaradia and Caricchi, 2017). Modelling combined with experimental results on metal partition coefficients, petrographic observations, and data compilation for real-case sulfide mineral analysis can help address this question.

\section{Conclusions}

In this study we have investigated magmatic sulfide occurrence and chemistry during the evolution of different magma types (from high-K calc-alkaline to shoshonitic series) in study areas characterised by diverse geodynamic settings (post-subduction, syn-subduction, and OIB intraplate volcanism). Our data allow us to draw the following conclusions: (1) sulfide saturation occurred in magmatic rocks from all study areas independently of the magma composition, geodynamic regimes, and whether or not the system produced an economic deposit. Sulfides were present in all rocks, corresponding to a wide range of composition $\left(\mathrm{SiO}_{2}\right.$ range $46 \mathrm{wt} \%-68 \mathrm{wt} \%$, basalts to andesites-dacites and from high-K calc-alkaline to shoshonitic series) and characterised by different geodynamic regimes (subduction, post-collision, and intraplate OIB volcanism), some of which are associated with economic deposits (porphyry $\mathrm{Cu}$ and/or $\mathrm{Au}$ and $\mathrm{Au}$ epithermal). (2) According to their occurrence and chemical composition, sulfides can be classified into different types which do not appear in all study areas. Type 
1 sulfides are rare, mostly composed of $\mathrm{Cu}$-poor phases (pyrrhotite, pentlandite-mss), hosted only by olivine phenocrysts, and seen only in Kula. Type 2 sulfides consist of a Cu-poor phase (pyrrhotite, \pm pentlandite) and a $\mathrm{Cu}$-rich phase (cubanite, chalcopyrite). They are the most abundant type, are hosted by different minerals (pyroxene, amphibole, magnetite, and plagioclase), and are found in all study areas. Type 3 sulfides are rare, composed of mostly a $\mathrm{Cu}$-rich phase (chalcopyrite \pm chalcocite) and pyrite, hosted by magnetite, and observed only in Beydagi. Type 4 sulfides are less abundant than Type-2 but more abundant than Type 1 and 3 . They are composed of only $\mathrm{Cu}$-rich phases (chalcopyritebornite \pm digenite), hosted only by magnetite, and observed solely in Konya and Ecuador. Type 5 sulfides are found in the groundmass as sulfide-oxide-silicate aggregates: they are mostly found in Kula and the sulfides are mainly $\mathrm{Cu}$-poor. Type 3 and 4 are the sulfides with the highest $\mathrm{Cu}$ contents and are only observed in areas associated with porphyry Au and $\mathrm{Cu}$ deposits, respectively, together with epithermal $\mathrm{Au}$ deposits. (3) As the sulfide melt evolves, a decrease in $\mathrm{Ni} / \mathrm{Cu}$ is observed, which is used here as a proxy for the mss / iss ratio. This chemical evolution corresponds to a sulfide melt evolution starting with an mss-rich sulfide melt, switching to an mss and iss melt, and finally (and uniquely for some settings) to iss-only sulfides. This suggests at least two sulfide saturating stages: an early mss-only or mss-rich and a late iss-only or iss-rich stage. Further research needs to address the question of whether these stages are distinct or are part of a continuous process of sulfide saturation. (4) The initial metal content of the magma was very similar for all the study areas. This can be inferred from the similar proportions of the mss and iss in the early-saturating-stage sulfide (Type 2) for all investigated study areas (mss $=84.2$ and iss $=15.7$ area \%, with $2 \mathrm{se}= \pm 2.2$ ). Based on points (2) and (4) above, the correlation between sulfides high in $\mathrm{Cu}$ and ore deposits (Beydagi, Konya, and Ecuador), combined with the similar mss and iss proportions in rocks from all study areas, suggests that the $\mathrm{Cu}$ contents of the sulfides and, potentially, of the later hydrothermal ore-forming fluids (e.g. Nadeau et al., 2010) increase concurrently with a $\mathrm{Cu}$ depletion of the residual magma. This possibly suggests that metal enrichment in derivative magmas is not an essential requirement for the fertility of the latter and that other factors associated with magma evolution $\left(\mathrm{H}_{2} \mathrm{O}\right.$ content, magma volume; Rohrlach and Loucks, 2005; Chiaradia and Caricchi, 2017) could play a more important role.

Data availability. Data are available from the figshare repository at https://doi.org/10.6084/m9.Figshare.8230787 (Georgatou and Chiaradia, 2019).

Supplement. The supplement related to this article is available online at: https://doi.org/10.5194/se-11-1-2020-supplement.
Author contributions. AAG and MC designed the project and methodology. AAG carried out the petrographical investigation, EPMA sulfide analysis, and bulk rock chemical analysis. AAG wrote the paper with contributions from MC.

Competing interests. The authors declare that they have no conflict of interest.

Acknowledgements. We would like to acknowledge Luca Paolillo, Florian Franziskakis, Bastien Deriaz, and Pablo Lormand for collecting samples from the Usak-Güre basin and from the Konya volcanic belt during fieldwork in May 2016, as well as conducting part of the whole rock analysis in the framework of their Master Thesis supervised by Chiaradia Massimo at the University of Geneva. We are grateful to the Editor Johan Lissenberg, as well as to the two referees Dan Smith and Jonathan Naden for their valuable and thorough revision of this study, which improved the original paper.

Financial support. This research has been supported by the Swiss National Science Foundation (grant no. 200021_169032).

Review statement. This paper was edited by Johan Lissenberg and reviewed by Jonathan Naden and Dan Smith.

\section{References}

Agangi, A. and Reddy, S. M.: Open-system behaviour of magmatic fluid phase and transport of copper in arc magmas at Krakatau and Batur volcanoes, Indonesia, J. Volcanol. Geoth. Res., 327, 669-686, https://doi.org/10.1016/j.jvolgeores.2016.10.006, 2016.

Agostini, S., Doglioni, C., Innocenti, F., Manetti, P., Tonarini, S., and Savaşçin, M. Y.: The transition from subductionrelated to intraplate Neogene magmatism in the Western Anatolia and Aegean area, Geol. S. Am. S., 418, 1-15, https://doi.org/10.1130/2007.2418(01), 2007.

Aldanmaz, E.: Mantle source characteristics of alkali basalts and basanites in an extensional intracontinental plate setting, western Anatolia, Turkey: implications for multi-stage melting, Int. Geol. Rev., 44, 440-457, https://doi.org/10.2747/0020-6814.44.5.440, 2002.

Aldanmaz, E., Pickard, M., Meisel, T., Altunkaynak, Ş., Sayıt, K., Şen, P., Hanan, B. B., and Furman, T.: Source components and magmatic processes in the genesis of Miocene to Quaternary lavas in western Turkey: Constraints from HSE distribution and Hf-Pb-Os isotopes, Contrib. Mineral. Petrol., 170, 1-20, https://doi.org/10.1007/s00410-015-1176-x, 2015.

Alici, P., Temel, A., and Gourgaud, A.: $\mathrm{Pb}-\mathrm{Nd}-\mathrm{Sr}$ isotope and trace element geochemistry of Quaternary extension-related alkaline volcanism: a case study of Kula region (Western Anatolia, Turkey), J. Volcanol. Geoth. Res., 115, 487-510, https://doi.org/10.1016/S0377-0273(01)00328-6, 2002. 
Audétat, A. and Pettke, T.: Evolution of a Porphyry-Cu Mineralized Magma System at Santa Rita, New Mexico (USA), J. Petrol., 47, 2021-2046, https://doi.org/10.5382/SP.16.21, 2006.

Audétat, A. and Simon A. C.: Magmatic controls on porphyry copper genesis, in: Geology and Genesis of Major Copper Deposits and Districts of the World: A Tribute to Richard H. Sillitoe, edited by: Hedenquist, J. W. Harris, M., and Camus, F., Soc. Econ. Geol., 16, 553-572, 2012.

Baker, T., Bickford, D., Juras, S., Oztas, Y., Ross, K., Tukac, A., Rabayrol, F., Miskovic, A., Friedman, R., Creaser, A. R., and Spikings, R.: The Geology of the Kişladağ porphyry gold deposit, Turkey, Soc. Econ. Geol., 19, 57-83, 2016.

Barnes, S. J., Holwell, D. A., and Le Vaillant, M.: Magmatic sulfide ore deposits, Elements, 13, 91-97, https://doi.org/10.2113/gselements.13.2.89, 2017.

Berlo, K., van Hinsberg, V. J., Vigouroux, N., Gagnon, J. E., Williams-Jones, A. E.: Sulfide breakdown controls metal signature in volcanic gas at Kawah Ijen volcano, Indonesia, Chem. Geol., 371, 115-127, https://doi.org/10.1016/j.chemgeo.2014.02.009, 2014.

Blundy, J., Mavrogenes, J. A., Tattitch, B., Sparks, S., and Gilmer, A.: Generation of porphyry copper deposits by gasbrine reaction in volcanic arcs, Nat. Geosci., 8, 235-240, https://doi.org/10.1038/ngeo2351, 2015.

Brennecka, G.: Origin and metal content of magmatic sulfides in $\mathrm{Cu}-\mathrm{Au}$ mineralizing silicic magmas: Yerington, Nevada and Yanacocha, Peru, MS thesis, Oregon State University, available at: https://ir.library.oregonstate.edu/concern/graduate_thesis_or_ dissertations/rn301373p (last access: 5 March 2006), 2006.

Cabri, L. J.: New data on phase relations in the $\mathrm{Cu}-\mathrm{Fe}-\mathrm{S}$ system, Econ. Geol., 68, 443-454, https://doi.org/10.2113/gsecongeo.68.4.443, 1973.

Çemen, I., Catlos, E. J., Gogus, O. H., and Ozerdem, C.: Postcollisional extensional tectonics and exhumation of the Menderes massif in the Western Anatolia extended terrane, Turkey, Geol. Soc. Am., 409, 353-379, https://doi.org/10.1130/2006.2409(18), 2006.

Chang, J. and Audétat, A.: Petrogenesis and Metal Content of Hornblende- Rich Xenoliths from Two Laramideage Magma Systems in Southwestern USA: Insights into the Metal Budget of Arc Magmas, J. Petrol., 59, 1869-1898, https://doi.org/10.1093/petrology/egy083, 2018.

Chelle-Michou, C., Rottier, B., Caricchi, L., Simpson, G.: Tempo of magma degassing and the genesis of porphyry copper deposits, Sci Rep.-UK, 7, 40566, https://doi.org/10.1038/srep40566, 2017.

Chiaradia, M.: Copper enrichment in arc magmas controlled by overriding plate thickness, Nat. Geosci., 7, 43-46, https://doi.org/10.1038/ngeo2028, 2014.

Chiaradia, M. and Caricchi, L.: Stochastic modelling of deep magmatic controls on porphyry copper deposit endowment, Sci. Rep.-UK, 7, 44523, https://doi.org/10.1038/srep44523, 2017.

Cline, J. S. and Bodnar, R. J.: Can economic porphyry copper mineralization be generated by a typical calc-alkaline melt?, J. Geophys. Res., 96, 8113-8126, https://doi.org/10.1029/91JB00053, 1991.

Cocker, H. A., Valente, D. L., Park, J.-W., and Campbell, I. H.: Using platinum group elements to identify sulfide saturation in a porphyry $\mathrm{Cu}$ system: the $\mathrm{El}$ Abra porphyry $\mathrm{Cu}$ deposit, Northern Chile, J. Petrol., 56, 2491-2514, 2015.
Cooke, D. R., Hollings, P., and Walsh, J. L.: Giant porphyry deposits: characteristics, distribution, and tectonic controls, Econ. Geol., 100, 801-818, https://doi.org/10.1093/petrology/egv076, 2005.

Core, P., Kesler, S. E., and Essene, E. J.: Unusually $\mathrm{Cu}-$ rich magmas associated with giant porphyry copper deposits: Evidence from Bingham, Utah, Geology, 34, 41-44, https://doi.org/10.1130/G21813.1, 2006.

Craig, J. R. and Kullerud, G.: Phase relations in the $\mathrm{Cu}-\mathrm{Fe}-\mathrm{Ni}-\mathrm{S}$ system and their application to magmatic ore deposits, Magmatic Ore Deposits, H. D. B. Wilson, 1969.

Craig, J. R. and Scott, S. D.: Sulfide phase equilibria, in: Sulfide Mineralogy - Short Course Notes, 1, edited by: Ribbe, P. H., Mineralogical Society of America, Southern Printing Co., Blacksburg, Virginia, CS1-110, ISBN 13 978-0-939950-01$0,1974$.

Delibaş, O., Moritz, R., Ulianov, A., Chiaradia, M., Saraç, C., Revan, K. M., and Göç, D.: Cretaceous subductionrelated magmatism and associated porphyry-type $\mathrm{Cu}-\mathrm{Mo}$ prospects in the Eastern Pontides, Turkey: new constraints from geochronology and geochemistry, Lithos, 248, 119-137, https://doi.org/10.1016/j.lithos.2016.01.020, 2016.

Delibaş, O., Moritz, R., Chiaradia, M., Selby, D., Ulianov, A., and Revan, K. M.: Post-collisional magmatism and oreforming systems in the Menderes massif: new constraints from the Miocene porphyry Mo-Cu Pınarbaşı system, GedizKütahya, western Turkey, Miner. Deposita, 52, 1157-1178, https://doi.org/10.1007/s00126-016-0711-7, 2017.

Dilek, Y. and Altunkaynak, Ş.: Cenozoic crustal evolution and mantle dynamics of post-collisional magmatism in western Anatolia, Int. Geol. Rev., 49, 431-453, https://doi.org/10.2747/00206814.49.5.431, 2007.

Dilek, Y., Imamverdiyev, N., and Altunkaynak, S.: Geochemistry and tectonics of Cenozoic volcanism in the Lesser Caucasus (Azerbaijan) and the peri-Arabian region: collision-induced mantle dynamics and its magmatic fingerprint, Int. Geol. Rev., 52, 536-578, https://doi.org/10.1080/00206810903360422, 2010.

Doglioni, C., Agostini, S., Crespi, M.., Innocenti, F., Manetti, P., Riguzzi, F., and Savascin, Y.: On the extension in western Anatolia and the Aegean Sea, J. Virtual Explorer, 8, 169-183, https://doi.org/10.3809/jvirtex.2002.00049, 2002.

Doglioni, C., Tonarini, S., and Innocenti, F.: Mantle wedge asymmetries and geochemical signatures along W- and E-NE-directed subduction zones, Lithos, 113, 179-189, https://doi.org/10.1016/j.lithos.2009.01.012, 2009.

Du, Y., Qin, X., Barnes, C. G., Cao, Y., Dong, Q., and Du, Y.: Sulfide melt evolution in upper mantle to upper crust magmas Tongling, China, Geosci. Front., 5, 237-248, https://doi.org/10.1016/j.gsf.2013.06.003, 2014.

Ercan, T. and Oztunali, O.: Characteristic features and "base surges" bed forms of Kula volcanics, Bull. Geol. Soc. Turkey, 25, 117 125, 1982 (in Turkish with English abstract).

Ercan, T., Dincel, A., Metin, S., Turkecan, A., and Gunay, E.: Geology of the Neogene basins in the Usak region, Bull. Min. Res. Exploration., 21, 97-106, 1978 (in Turkish).

Ercan, T., Türkecan, A., Dinçel, A., and Günay, A.: Geology of Kula-Selendi (Manisa) area, Geol. Eng., 17, 3-28, 1983 (in Turkish). 
Ersoy, E. Y., Helvacı, C., and Palmer, M. R.: Mantle source characteristics and melting models for the early-middle Miocene mafic volcanism in Western Anatolia: implications for enrichment processes of mantle lithosphere and origin of K-rich volcanism in post-collisional settings, J. Volcanol. Geoth. Res., 198, 112-128, https://doi.org/10.1016/j.jvolgeores.2010.08.014, 2010.

Feininger, T. and Seguin, M. K.: Simple Bouguer gravity anomaly field and the inferred crustal structure of continental Ecuador, Geology, 11, 40-44, https://doi.org/10.1130/00917613(1983)11<40:SBGAFA>2.0.CO;2, 1983.

Fontboté, L., Kouzmanov, K., Chiaradia, M., and Pokrovski, G. S.: Sulfide minerals in hydrothermal deposits, Elements, 13, 97103, https://doi.org/10.2113/gselements.13.2.97, 2017.

Fournelle, J., Carmody, R., and Daag, A. S.: Anhydrite-Bearing Pumices from the June 15, 1991, Eruption of Mount Pinatubo, Geochemistry, Mineralogy, and Petrology, available at: https: //pubs.usgs.gov/pinatubo/four/, last access: 6 October 1999.

Fulignati, P., Gioncada, A., Costa, S., Di Genova, D., Di Traglia, F., and Pistolesi, M.: Magmatic sulfide immiscibility at an active magmatic-hydrothermal system: The case of La Fossa (Vulcano, Italy), J. Volcanol. Geoth. Res., 358, 45-57, https://doi.org/10.1016/j.jvolgeores.2018.06.009, 2018.

Georgatou, A. A. and Chiaradia, M.: Supplementary dataset to article Magmatic sulfides in high-potassium calc-alkaline to shoshonitic and alkaline rocks, Figshare data repository, https://doi.org/10.6084/m9.Figshare.8230787, 2019.

Georgatou, A. A., Chiaradia, M., Rezeau, H., and Walle, M.: Magmatic sulfides in Quaternary Ecuadorian arc magmas, Lithos, 296-299, 580-599, https://doi.org/10.1016/j.lithos.2017.11.019, 2018.

Greaney, A. T., Rudnick, R. L., Helz, R. T., Gaschning, R. M., Piccoli, P. M., and Ash, R. D.: The behavior of chalcophile elements during magmatic differentiation as observed in Kilauea Iki lava lake, Hawaii, Geochim. Cosmochim. Ac., 210, 71-96, https://doi.org/10.1016/j.gca.2017.04.033, 2017.

Grutzner, T., Prelević, D., and Cüneyt, A.: Geochemistry and origin of ultramafic enclaves and their basanitic host rock from Kula Volcano, Turkey, Lithos, 180-181, 58-73, https://doi.org/10.1016/j.lithos.2013.08.001, 2013.

Guillier, B., Chatelain, J., Jaillard, E., Yepes, H., Poupinet, G., and Fels, J.: Seismological evidence on the geometry of the orogenic system in central-northern Ecuador (South America), Geophys. Res. Lett., 28, 3749-3752, https://doi.org/10.1029/2001GL013257, 2001.

Hall, D. J., Foster, R. P., Yildiz, B., and Redwood, S. D.: The Inlice High-sulphidation Epithermal Gold Discovery: Defining a Potential New Gold Belt in Turkey, in: Digging Deeper, edited by: Andrew, C. J., Proceedings of the Ninth Biennial Meeting of the Society for Geology Applied to Mineral Deposits (January), 113-116, 2007.

Halter, W. E., Heinrich, C. A., and Pettke, T.: Magma evolution and the formation of porphyry $\mathrm{Cu}-\mathrm{Au}$ ore fluids: evidence from silicate and sulfide melt inclusions, Miner. Deposita, 39, 845-863, https://doi.org/10.1007/s00126-004-0457-5, 2005.

Harmon, R. S., Hoefs, J., and Wedepohl, K. H.: Stable isotope $(\mathrm{O}, \mathrm{H}, \mathrm{S})$ relationships in Tertiary basalts and their mantle xenoliths from the Northern Hessian Depression, W. Germany., Contrib. Mineral. Petrol., 95, 350-369, https://doi.org/10.1007/BF00371849, 1987.
Hattori, K.: High-sulfur magma, a product of fluid discharge from underlying mafic magma: Evidence from Mount Pinatubo, Philippines, Geology, 21, 1083-1086, https://doi.org/10.1130/00917613(1993)021<1083:HSMAPO>2.3.CO;2, 1993.

Hattori, K.: Occurrence and origin of sulfide and sulfate in the 1991 Mount Pinatubo eruption products, in: Fire and Mud: Eruptions and Lahars of Mount Pinatubo, Philippines, edited by: Newhall, C. G. and Punongbayan, R. S., University of Washington Press, 807-824, USGS, available at: https://pubs.usgs.gov/ pinatubo/hattori/ (last access: 6 October 1999), 1996.

Holwell, D. A. and McDonald, I.: A review of the behaviour of platinum group elements within natural magmatic sulfide ore systems, Platin. Met. Rev., 54, 26-36, https://doi.org/10.1595/147106709X480913, 2010.

Holwell, D. A., Keays, R., McDonald, I., and Williams, M.: Extreme enrichment of Se, Te, PGE and $\mathrm{Au}$ in $\mathrm{Cu}$ sulfide microdroplets: evidence from LA-ICP-MS analysis of sulfides in the Skaergaard Intrusion, east Greenland, Contrib. Mineral. Petr., 170, 53, https://doi.org/10.1007/s00410-015-1203-y, 2015.

Hou, Z., Zhang, H., Pan, X., and Yang, Z.: Porphyry $\mathrm{Cu}$ (-Mo-Au) deposits related to melting of thickened mafic lower crust: examples from the eastern Tethyan metallogenic domain, Ore Geol. Rev., 39, 21-45, https://doi.org/10.1016/j.oregeorev.2010.09.002, 2011.

Hou, Z., Zhou, Y., Wang, R., Zheng, Y., He, W., Zhao, M., Evans, N. J., and Weinberg, R. F.: Recycling of metalfertilized lower continental crust: Origin of non-arc Au-rich porphyry deposits at cratonic edges, Geology, 45, 563-566, https://doi.org/10.1130/G38619.1, 2017.

Innocenti, F., Agostini, S., Di Vincenzo, G., Doglioni, C., Manetti, P., Savaşçin, M. Y., and Tonarini, S.: Neogene and Quaternary volcanism in Western Anatolia: magma sources and geodynamic evolution, Mar. Geol., 221, 397-421, https://doi.org/10.1016/j.margeo.2005.03.016, 2005.

Jenner, F. E.: Cumulate causes for the low contents of sulfide-loving elements in the continental crust, Nat. Geosci., 10, 524-529, https://doi.org/10.1038/ngeo2965, 2017.

Jenner, F. E., O’Neill, H. S. T. C., Arculus, R. J., and Mavrogenes, J. A.: The magnetite crisis in the evolution of arc-related magmas and the initial concentrations of $\mathrm{Au}, \mathrm{Ag}$, and $\mathrm{Cu}$, J. Petrol., 51, 2445-2464, https://doi.org/10.1093/petrology/egq063, 2010.

Jensen, E.: Pyrrhotite: melting relations and composition, Am. J. Sci., 240, 695-709, https://doi.org/10.2475/ajs.240.10.695, 1942.

Karaoğlu, Ö., Helvac1, C., and Ersoy, Y.: Petrogenesis and ${ }^{40} \mathrm{Ar} /{ }^{39} \mathrm{Ar}$ geochronology of the volcanic rocks of the Uşak-Güre basin, western Türkiye, Lithos, 119, 193-210, https://doi.org/10.1016/j.lithos.2010.07.001, 2010.

Keith, J. D., Whitney, J. A., Hattori, K., Ballantyne, G. H., Christiansen, E. H., Barr, D. L., Cannan, T. M., and Hook, C. J.: The role of magmatic sulfides and mafic alkaline magmas in the Bingham and Tintic mining districts, Utah, J. Petrol., 3, 1679-1690, https://doi.org/10.1093/petroj/38.12.1679, 1997.

Keith, M., Haase, K., Klemd, R., Schwarz-Schampera, U., and Franke, H.: Systematic variations in magmatic sulfide chemistry from mid-ocean ridges, backarc basins and island arcs, Chem. Geol., 451, 67-77, https://doi.org/10.1016/j.chemgeo.2016.12.028, 2017. 
Keller, J., Burgath, K., Jung, D., and Wolff, F.: Geologie und petrologie des neogenen kalkalkali-vulkanismus von Konya (Erenler Dag-Alaca Dag-Massiv, Zentral-Anatolien), Geologisches Jahrbuch, 25, 37-117, 1977.

Kelley, K. A. and Cottrell, E.: Water and the oxidation state of subduction zone magmas, Science, 325, 605-607, https://doi.org/10.1126/science.1174156, 2009.

Kitakaze, A.: Sulfide blebs in the andesite from Kasayama volcano, Hagi-city, Yamaguchi, Japan, 39, 190-192, https://doi.org/10.2465/gkk.091220, 2010.

Korkmaz, G., Kursad, A., Huseyin, K., and Ganerod, M.: ${ }^{40} \mathrm{Ar} /{ }^{39} \mathrm{Ar}$ geochronology, elemental and $\mathrm{Sr}-\mathrm{Nd}-\mathrm{Pb}$ isotope geochemistry of the Neogene bimodal volcanism in the Yükselen area, NW Konya (Central Anatolia, Turkey), J. African Earth Sci., 129, 427-444, 2017.

Kullerud, G., Yund, R. A., and Moh, G. H.: Phase relation in the $\mathrm{Cu}-$ $\mathrm{Fe}-\mathrm{Ni}, \mathrm{Cu}-\mathrm{Ni}-\mathrm{S}$ and Fe-Ni-S systems, Econ. Geol., 4, 323-343, https://doi.org/10.1016/j.jafrearsci.2017.02.001, 1969.

Larocque, A. C., Stimac, J. A., Keith, J. D., and Huminicki, M. A.: Evidence for open-system behavior in immiscible Fe-S-O liquids in silicate magmas: implications for contributions of metals and sulfur to ore-forming fluids, Can. Mineral., 38, 1233-1249, https://doi.org/10.2113/gscanmin.38.5.1233, 2000.

Lee, C.-T. A., Luffi, L. P., Chin, E. J., Bouchet, R., Dasgupta, R., Morton, D. M., Roux, V. L., Yin, Q., and Jin, D.: Copper Systematics in Arc Magmas and Implications for Crust-Mantle Differentiation, Science, 336, 64-68, https://doi.org/10.1126/science.1217313, 2012.

Li, J., Qin, K. Z., and Li, G.: Basic characteristics of gold-rich porphyry copper deposits and their ore sources and evolving processes of high oxidation magma and ore-forming fluid, Acta Petrol. Sin., 22, 678-688, 2006.

Lowczak, J. N., Campbell, I. H., Cocker, H., Park, J. W., and Cooke, D. R.: Platinum-group element geochemistry of the Forest Reef Volcanics, Southeastern Australia: Implications for porphyry $\mathrm{Au}-\mathrm{Cu}$ mineralisation, Geochim. Cosmochim. Ac., 220, 385-406, https://doi.org/10.1016/j.gca.2017.09.052, 2018.

Loucks, R. B.: Distinctive composition of copper-oreforming arc magmas, Aust. J. Earth Sci., 61, 5-16, https://doi.org/10.1080/08120099.2013.865676, 2014.

Mandon, C. L.: Volatile transport of metals in the andesitic magmatic-hydrothermal system of White Island, MS thesis, Victoria University of Wellington, available at: http://hdl.handle.net/ 10063/6730 (last access: 9 December 2019), 2017.

Mathez, E. A. and Yeats, R. S.: Magmatic Sulfides in Basalt Glass from DSDP Hole 319A and Site 320, Nazca Plate, Geol., https://doi.org/10.2973/dsdp.proc.34.123.1976, 1976.

Metrich, N., Berry, A. J., O'Neill, H. S., and Susini, J.: The oxidation state of sulfur in synthetic and natural glasses determined by X-ray absorption spectroscopy, Geochim. Cosmochim. Ac., 73, 2382-2399, https://doi.org/10.1016/j.gca.2009.01.025, 2009.

Mungall, J. and Brenan, J.: Partitioning of platinum-group elements and $\mathrm{Au}$ between sulfide liquid and basalt and the origins of mantle-crust fractionation of the chalcophile elements, Geochim. Cosmochim. Ac., 125, 265-289, https://doi.org/10.1016/j.gca.2013.10.002, 2014.

Nadeau, O., Williams-Jones, A. E., and Stix, J.: Sulfide magma as a source of metals in arc-related magmatic hydrothermal ore flu- ids, Nat. Geosci., 3, 501-505, https://doi.org/10.1038/ngeo899, 2010.

Naldrett, A.: Magmatic Sulfide Deposits Geology, Geochemistry and Exploration, Chapter 2: Theoretical considerations, Springer Science and Business Media, ISBN 978366208444 1, 2013.

Naldrett, A. and Gasparrini, E.: Archean nickel sulfide deposits in Canada: their classification geological setting and genesis with some suggestions as to exploration, Geol. Soc. Aust. S., 3, 201226, https://doi.org/10.1007/978-3-662-08444-1. 1971.

Parat, F., Holtz, F., and Streck, M. J.: Sulfur-bearing Magmatic Accessory Minerals, Rev. Mineral. Geochem., 73, 285-314, https://doi.org/10.2138/rmg.2011.73.10, 2011.

Park, J. W., Campbell, I., Kim, J., and Moon, J.-W.: The role of sulfide saturation on formation of a $\mathrm{Cu}$ - and Au-rich magma: insights from the platinum group element geochemistry of Niuatahi-Motutahi lavas, Tonga rear arc, J. Petrol., 56, 59-81, https://doi.org/10.1093/petrology/egu071, 2015.

Park, J.-W., Campbell, I. H., Malaviarachchi, S. P. K., Cocker, H., Hao, H., and Kay, S. M.: Chalcophile element fertility and the formation of porphyry $\mathrm{Cu} \pm \mathrm{Au}$ deposits, Miner. Deposita, 54, 657-670, https://doi.org/10.1007/s00126-018-0834-0, 2019.

Patten, C., Barnes, S. J., and Mathez, E. A.: Textural variations in MORB sulfide droplets due to differences in crystallization history, Can. Mineral., 50, 675-692, https://doi.org/10.3749/canmin.50.3.675, 2012.

Pe-Piper, G. and Piper, D. J.: Late Cenozoic, post-collisional Aegean igneous rocks: $\mathrm{Nd}, \mathrm{Pb}$ and $\mathrm{Sr}$ isotopic constraints on petrogenetic and tectonic models, Geol. Mag., 138, 653-668, https://doi.org/10.1017/S0016756801005957, 2001.

Prelević, D., Akal, C., Foley, S. F., Romer, R. L., Stracke, A., and Van Den Bogaard, P.: Ultrapotassic mafic rocks as geochemical proxies for post-collisional dynamics of orogenic lithospheric mantle: the case of southwestern Anatolia, Turkey, J. Petrol., 53, 1019-1055, https://doi.org/10.1093/petrology/egs008, 2012.

Qin, X. L., Du, Y. S., Tian, S. H., Lee, H. K., Yin, J. W., and Kim, S. J.: Discovery of pyrrhotitechalcopyrite-bearing amphibole megacrysts in Tongling area, Anhui Province, J. China Univ. Geosci., 15, 36-45, 2004.

Rabayrol, F., Hart, C. J. R., and Thorkelson, D. J.: Temporal, spatial and geochemical evolution of late Cenozoic post-subduction magmatism in central and eastern Anatolia, Turkey, Lithos, 336337, 67-96, https://doi.org/10.1016/j.lithos.2019.03.022, 2019.

Redwood, S. D.: Exploration of the Doğanbey Project, Konya, Turkey, Report for Stratex International plc, 26 April 2006, London, 2006.

Richards, J. P.: Postsubduction porphyry $\mathrm{Cu}-\mathrm{Au}$ and epithermal $\mathrm{Au}$ deposits: Products of remelting of subduction-modified lithosphere, Geology, 37, 247-250, https://doi.org/10.1130/G25451A.1, 2009.

Richards, J. P.: High $\mathrm{Sr} / \mathrm{Y}$ arc magmas and porphyry $\mathrm{Cu}$ Mo Au deposits: Just add water, Econ. Geol., 106, 1075-1081, https://doi.org/10.2113/econgeo.106.7.1075, 2011.

Richards, J. P.: Giant ore deposits form by optimal alignments and combinations of geological processes, Nat. Geosci., 6, 911-916, https://doi.org/10.1038/ngeo1920, 2013.

Richards, J. P. and Kerrich, R.: Special Paper: AdakiteLike Rocks: Their Diverse Origins and Questionable Role in Metallogenesis, Econ. Geol., 102, 537-576, https://doi.org/10.2113/gsecongeo.102.4.537, 2007. 
Richardson-Bunbury, J. M.: The Kula volcanic field, western Turkey; the development of a Holocene alkali basalt province and the adjacent normal-faulting graben, Geol. Mag., 133, 275283, https://doi.org/10.1017/S0016756800009018, 1996.

Rohrlach, B. D. and Loucks, R. P.: Multi-million-year cyclic rampup of volatiles in a lower crustal magma reservoir trapped below the Tampakan copper-gold deposit by Mio-Pliocene crustal compression in the southern Philippines, in: Super Porphyry Copper \& Gold Deposits - A Global Perspective, edited by: Porter, T. M., PGC Publishing, Adelaide, 2, 369-407, 2005.

Savelyev, D. P., Kamenetsky, V. S., Danyushevsky, L. V., Botcharnikov, R. E., Kamenetsky, M. B., Park, J.-W., Portnyagin, M. V., Olin, P., Krasheninnikov, S. P., and Hauff, F.: Immiscible sulfide melts in primitive oceanic magmas: Evidence and implications from picrite lavas (Eastern Kamchatka, Russia), Am. Mineral., 103, 886-898, https://doi.org/10.2138/am-2018-6352, 2018.

Schütte, P., Chiaradia, M., Barra, F., Villagómez, D., and Beate, B.: Metallogenic features of Miocene porphyry $\mathrm{Cu}$ and porphyryrelated mineral deposits in Ecuador revealed by Re-Os, ${ }^{40} \mathrm{Ar} /{ }^{39} \mathrm{Ar}$, and U-Pb geochronology, Miner. Deposita, 47, 383410, https://doi.org/10.1007/s00126-011-0378-z, 2012.

Seyitoglu, G.: Late Cenozoic tectono-sedimentary development of the Selendi and Usak-Güre basins: a contribution to the discussion on the development of east-west and north trending basins in western Turkey, Geol. Mag., 134, 163-175, https://doi.org/10.1017/S0016756897006705, 1997.

Shafiei, B., Haschke, M., and Shahabpour, J.: Recycling of orogenic arc crust triggers porphyry $\mathrm{Cu}$ mineralisation in Kerman Cenozoic arc rocks, south-eastern Iran, Miner. Deposita, 44, 265-283, https://doi.org/10.1007/s00126-008-0216-0, 2009.

Sillitoe, R. H.: A Plate Tectonic Model for the Origin of Porphyry Copper Deposits, Econ. Geol., 67, 184-197, https://doi.org/10.2113/gsecongeo.67.2.184, 1972.

Sillitoe, R. H.: Gold-rich porphyry copper deposits: Geological model and exploration implications, Geol. Assoc. Can. S., 40, 465-478, 1993.

Sillitoe, R. H.: Some metallogenic features of gold and copper deposits related to alkaline rocks and consequences for exploration, Miner. Deposita, 37, 4-13, https://doi.org/10.1007/s00126-0010227-6, 2002.

Sillitoe, R. H.: Copper provinces, in: Geology and Genesis of Major Copper Deposits and Districts of the World: A Tribute to Richard H. Sillitoe, edited by: Hedenquist, J. W., Harris, M., and Camus, F., Soc. Econ. Geol., 16, 1-18, 2012.

Stone, W. E. and Fleet, M. E.: Nickel-copper sulfides from the 1959 eruption of Kilauea Volcano, Hawaii: Constraining compositions and phase relations in eruption pumice and Kilauea Oki lava lake, Am. Mineral., 76, 1363-1372, 1991.

Stone, W. E., Fleet, M. E., and MacRae, N. D.: Two-phase nickeliferous monosulfide solid solution (mss) in megacrysts from Mount Shasta, California: A natural laboratory for nickel-copper sulfides, Am. Mineral., 74, 981-993, 1989.
Temel, A.: Post-collisional Miocene alkaline volcanism in the oglakçi region, Turkey, Petrol. Geochem. Int. Geol. Rev., 43, 640-660, https://doi.org/10.1080/00206810109465038, 2001.

Temel, A., Gundogdu, M. N., and Gourgaud, A.: Petrological and geochemical characteristics of Cenozoic high-K calcalkaline volcanism in Konya, Central Anatolia, Turkey, J. Volcanol. Geoth. Res., 85, 327-354, https://doi.org/10.1016/S03770273(98)00062-6, 1998.

Tokçaer, M., Agostini, S., and Savaşçın, M. Y.: Geotectonic setting and origin of the youngest Kula volcanics (western Anatolia), with a new emplacement model, Turk. J. Earth Sci., 14, 145-166, 2005.

Tsujimura, T. and Kitakaze, A.: New phase relations in the $\mathrm{Cu}-$ $\mathrm{Fe}-\mathrm{S}$ system at $800^{\circ} \mathrm{C}$; constraint of fractional crystallization of a sulfide liquid, Neues Jb. Miner. Monat., 10, 433-444, https://doi.org/10.1127/0028-3649/2004/2004-0433, 2004.

Westaway, R., Pringle, M., Yurtmen, S., Demir, T., Bridgland, D., Rowbotham, G., and Maddy, D.: Pliocene and Quaternary regional uplift in western Turkey: the Gediz River terrace staircase and the volcanism at Kula, Tectonophysics, 391, 121-169, https://doi.org/10.1016/j.tecto.2004.07.013, 2004.

Whitney, J. A. and Stormer, J. C.: Igneous sulfides in the Fish Canyon Tuff and the role of sulfur in calcalkaline magmas, Geology, 11, 2, https://doi.org/10.1130/00917613(1983)11<99:ISITFC>2.0.CO;2, 1983.

Wilke, M., Klimm, K., and Kohn, S. C.: Spectroscopic Studies on Sulfur Speciation in Synthetic and Natural Glasses, Rev. Mineral. Geochem., 73, 41-78, https://doi.org/10.2138/rmg.2011.73.3, 2011.

Wilkinson, J. J.: Triggers for the formation of porphyry ore deposits in magmatic arcs, Nat. Geosci., 6, 917-925, https://doi.org/10.1038/ngeo1940, 2013.

Yund, R. and Kullerud, G.: Thermal stability of assemblages in $\mathrm{Cu}-\mathrm{Fe}-\mathrm{S}$ system, J. Petrol., 7, 456-488, https://doi.org/10.1093/petrology/7.3.454, 1966.

Zelenski, M., Kamenetsky, V. S., Mavrogenes, J. A., Gurekno, A. A., and Danyushevsky, L. V.: Silicate-sulfide liquid immiscibility in modern arc basalt (Tolbachik volcano, Kamchatka): part I. Occurrence and compositions of sulfide melts, Chem. Geol., 471, 92-110, https://doi.org/10.1016/j.chemgeo.2017.09.019, 2017.

Zhang, D. and Audétat A.: Chemistry, mineralogy and crystallization conditions of porphyry Mo-forming magmas at UradHenderson and silver creek, Colorado, USA, J. Petrol., 58, 277296, https://doi.org/10.1093/petrology/egx016, 2017.

Zürcher, L., Bookstrom, A. A., Hammarstrom, J. M., Mars, J. C., Ludington, S., Zientek, M. L., Dunlap, P., Wallis, J. C., with contributions from Drew, L. J., Sutphin, D. M., Berger, B. R., Herrington, R. J., Billa, M., Kuşcu, I., Moon, C. J., and Richards, J. P.: Porphyry copper assessment of the Tethys region of western and southern Asia, U.S. Geol. Surv. Sci. Invest. Rep., 2010-5090, 232, and spatial data, https://doi.org/10.3133/sir20105090V, 2015. 